Mukaddime, 2021, 12(1), s. 69-99.

DOI: $10.19059 /$ mukaddime.820700

\title{
Mor Evgin ve Hristiyan Mistisizminin Tur Abdin Bölgesine Giriși
}

Şükran YAŞAR ${ }^{1}$

\section{Öz}

Türkiye'nin Güney Doğu Anadolu Bölgesi'nde, Mardin'in kuzey doğusunda Midyat merkezli dağlık bir alan olan, tarihsel ve dinsel açılardan taşıdığı değer nedeniyle Süryaniler tarafından âdeta kutsal bölge olarak görülen "Tur Abdin”, manastırlarıyla meşhur bir bölgedir. Söz konusu manastırlara ya da bölgedeki "monastik" yaşamın başlangııına dair anlatılarda IV. yüzyılda yaşadığı tahmin edilen Mor Evgin isimli Hristiyan bir münzevi öne çıkmaktadır. Zira Mor Evgin, Hristiyanlığın "monastik” yaşam tarzını Tur Abdin'e getiren kişi olarak kabul edilmektedir. Aslen Mısırlı olup rivayete göre zamanla burayı terk ederek 70 şakirdiyle birlikte Tur Abdin Bölgesi'ne gelmiş ve burada inzivaya çekilmiştir. Bölgenin ilk manastırı da muhtemelen Mor Evgin tarafından IV. yüzyılda kurulmuştur ve bugün de onun ismiyle tanımlanmaktadır. O, İzlo Dağı eteklerindeki bu manastırda yetiştirdiği rahiplerle kısa zaman zarfında bölgede ve civarında çok sayıda başka manastırın inşasına da öncülük etmiştir. Bu bağlamda denilebilir ki, Mor Evgin ve Mor Evgin Manastırı, âdeta bir tarihin, bir devrin başlatıcısı olmuşlardır. Gerek din eğitiminde, gerek dini kurumsal yapılanmada ve gerekse kitlelerin dinî yaşantısında manastırların fonksiyonel rolü anlaşılmadan Doğu Hristiyanlığını anlamak mümkün değildir. Katolik ve Batı Ortodoks (Bizans ve Balkan coğrafyası) dünyasında Kilise'nin itikadî ve amelî ilke ve uygulamaları Papalık / Patrikhane Sen-Sinodu'nda oluşurken, Doğu Hristiyanlığı'nın (Süryaniler, Keldaniler, Nasturiler, Marunîler, Kıptiler, Ermeniler...) itikadî ve amelî ilke ve uygulamalarının hayat bulduğu alan manastırlardır. Katolik ve Ortodoks dünyasında manastırlar, Kilise'nin kontrolündeki merkezler iken, örneğin Süryani dünyasında dinî anlayışın ana merkezleridir. Buralar sadece dünyadan el-etek çekmiş keşişlerin münzevi yaşam sürdürdükleri yerler değildir. Bu manastırlar, tarih boyunca farklı itikadî düşüncelerin mücadelesinin verildiği aksiyon merkezleri olarak Doğu Hristiyanlığı tarihinde önemli fonksiyonlar üstlenmişlerdir. Söz gelimi itikadî ilkeler buralarda belirlenmiş, ihtilafları çözen sinodlar buralarda toplanmış, Kilise'nin idari birimlerinde görev alan kadrolar buralardan yetişmiştir. Kilisenin dinî ve idari kararlarının alındığı Sen-Sinod'un üyeleri çoğunlukla manastır reislerinden oluşmuştur. Dini eğitim buralarda

1 Dr. Öğr. Üyesi, Manisa Celal Bayar Üniversitesi Edebiyat Fakültesi Tarih Bölümü, sukran.yasar@cbu.edu.tr, ORCID ID: 0000-0001-8943-4160. 
verilmiş, Kilise'nin başı olan Patrik bu manastırlardan birinde ikamet etmiştir. Bu makale, Süryani Hristiyanlığı özelinde Tur Abdin Bölgesi'nde başlayan ve gelişen monastik hayatı ana hatlarıyla anlatma ve bunun yanında bölgede monastik yaşamı tetikleyen bir yapı olarak Mor Evgin Manastırı hakkında tarihi ve mimari açılardan bilgi verme amacı taşımaktadır.

Anahtar Kelimeler: Mistisizm, manastır, Mor Evgin, Tur Abdin, Mor Evgin Manastırı.

\title{
Mor Evgin and Christian Misticism Introduction to Tur Abdin Region
}

\begin{abstract}
Turkey's Southeast Anatolia Region, which is a mountainous area northeast of Mardin's Midyat based, historical and regarded as a sacred area by the Assyrians in value due to the move from a religious perspective "Tur Abdin" is a region famous for its monastery. In the narratives about the monasteries in question or the beginning of monastic life in the region, a Christian hermit named Mor Evgin, who is estimated to have lived in the 4th century, stands out. Because Mor Evgin is considered to be the person who brought the monastic lifestyle of Christianity to Tur Abdin. Originally from Egypt, according to rumor, he left here over time and came to the Tur Abdin Region with 70 disciples and retreated here. The first monastery of the region was probably founded by Mor Evgin in the 4th century and is still identified with his name today. He led the construction of many other monasteries in and around the region in a short period of time with the priests he raised in this monastery at the foot of Izlo Mountain. In this context, it can be said that Mor Evgin and Mor Evgin Monastery became the initiator of a history and an era. It is not possible to understand Eastern Christianity without understanding the functional role of monasteries in religious education, in religious institutional structuring and in the religious life of the masses. In the Catholic and Western Orthodox (Byzantine and Balkan geography) world, the religious and practical principles and practices of the Church were formed in the Papal / Patriarchate Sen-Synod, while the Eastern Christianity (Assyrians, Chaldeans, Nestorians, Maronites, Copts, Armenians ...) The area where practical principles and practices come to life are monasteries. In the Catholic and Orthodox world, monasteries are backyards under the control of the Church, for example, they are the main centers of religious understanding in the Syriac world. These are not only places where the monks withdrawn from the world lead a reclusive life. These monasteries have undertaken important functions in the history of Eastern Christianity as action centers where different beliefs have been fought throughout history. For example, the principles of creed were determined here, the synods that resolved the disputes were gathered here, and the cadres working in the administrative
\end{abstract}


units of the Church were trained from here. The members of the SenSynod, where the religious and administrative decisions of the church were made, were mostly composed of monastic chiefs. Religious education was given here, the Patriarch, the head of the Church, resided in one of these monasteries. This article aims to outline the monastic life that started and developed in the Tur Abdin region, especially in Syriac Christianity, and also to give information about the Mor Evgin Monastery in historical and architectural terms as a structure that triggered the monastic life in the region.

Keywords: Mysticism, monastery, Mor Evgin, Tur Abdin, Mor Evgin Monastery.

\section{Extended Abstract}

Once Tur Abdin is mentioned, monasteries immediately come to mind. Tur Abdin means "Mount of God's Servants". Tur Abdin Region is basically in the center of Mardin-Midyat and it has been located in an area which is approximately $70 \mathrm{km2}$. There are currently 107 religious buildings in the region. None of the corners of the world has such a religious structure of this scale. Monasticism and mysticism were born in the Egyptian geography. It has developed here, and then, came to the Cappadocia Region under the leadership of St. Basil. Then, moved to the present Southeastern Anatolia Region known as Tur Abdin under the leadership of Mor Evgin. Being originally from Egypt, Evgin left here and came to the Tur Abdin region with 70 of his disciples and secluded himself in Izlo Mountain in Nusaybin. Mor Evgin Monastery was built by Mor Evgin in the 16th century and is the first monastery established in the entire region. Mor Evgin is the spiritual person who brought monasticism to Tur Abdin. He pioneered the construction of many monasteries in the entire Southeastern Anatolia Region and Northern Mesopotamia, especially in the Tur Abdin Region, with the monks he raised in the monastery named after him on the foothills of the Izlo Mountains. With the monastery he built here, he was the initiator of an era. It is not possible to understand Eastern Christianity without understanding the functional role of monasteries in religious education, in religious institutional structuring and in the religious life of the masses. In the Catholic and Western Orthodox (Byzantine and Balkan geography) world, the religious and practical principles and practices of the Church were formed in the Papal / Patriarchate Sen-Synod, while Eastern Christianity (Assyrians, Chaldeans, Nestorians, Maronites, Copts, Armenians ...) principles and practices come to life are monasteries. In the Catholic and Orthodox world, monasteries are the backyards controlled by the Church, while in the Syriac world they are the main centers of religious understanding. These are not just places where the monks have lived in seclusion. They have also played a very important functional role in the history of Eastern Christianity, as action centers where different religious ideas have been struggled throughout history. The strategic principles were determined from here, the sinodes that resolved the conflicts were gathered there, and the staff working in 
the administrative units of the Church were trained there. The members of Sen-Synod, where the religious and administrative decisions of the church were made, were mostly made up of the monastery heads. Religious education was provided here and the Patriarch, the head of the Church, was living in one of these monasteries. The most lively periods of monastic life in Tur Abdin's neighborhood was between the IV. - VII. th centuries. We observe that an important number of Eastern Christianity's famous clergy, theologians, philosophers and mystics grew up in this region during this period. They determined and explained the basic rules of monastic life and the philosophical foundations of spirituality in their works. The monastic life, which started with Mor Evgin and later gained a systematic structure in such a way that 90,000 monks are rumored to have lived in the monasteries in the region in the 5 th century. Therefore, this establishment cannot simply be regarded as the residence of some people who have lived a secluded life. Its meaning and significance in Eastern Christianity is more than it seems and predicted. In this article, primarily we will try to outline the monastic life that started and developed in the Tur Abdin region. Then, we will give information about Mor Evgin monastery (history / architecture), where the monastic life in the region began and was first established. 


\section{Giriş}

Hristiyan münzevi yaşamının tam olarak ne zaman ve nerede ortaya çıktığına dair elde kesin ve doğrudan kanıtlar yoktur. Ne var ki, ilk Hristiyan münzevi değilse bile ismen bilinen ilk Hristiyan münzevi olarak tanımlanabilecek Aziz Antonius (ö.356), Hristiyan monastisizminin başlangıcına dair bahislerde sık zikredilen Mısırlı bir efsanevi şahsiyettir. Benzer biçimde ve mevcut bazı bilgilerden hareketle, münzevi yaşam tarzının Kapadokya Bölgesi'ne gelmesinde IV. yüzyılda bölgenin önemli Kilise babalarından olan Aziz Basileios'un (ö. 379), Tur Abdin Bölgesi'ne ulaşmasında ise yine aynı yüzyılda Mor Evgin'in (ö. 363) önemli ve öncü rolleri olduğu kabul edilmektedir.

Tur Abdin, Süryanice "Tanrı Hizmetkârları Dağı” anlamına gelmektedir (Hollerweger, 1999: 24). Tur Abdin Bölgesi, ana hatlarıla Mardin-Midyat merkezli, takriben 70 km². lik bir alandır (Resim - 1). Bölgede hâli hazırda 107 adet dinî yapı mevcuttur.

Tur Abdin Bölgesi'nde kurulan ilk manastır, kurucusunun adını taşıyan Mor Evgin'dir. Mor Evgin, başta Tur Abdin olmak üzere, tüm Güneydoğu Anadolu Bölgesi ve Kuzey Mezopotamya'da çok sayıda manastırın inşasına öncülük etmiştir. Tur Abdin Bölgesi'nde Hristiyan ruhbanlar ve münzeviler kendilerine has bir Hristiyanlık anlayışının dinî ilke ve esaslarını bu manastırlarda üretmişlerdir. Bu bağlamda dinî eğitim buralarda verilmiş, Kilise'nin başı olan Patrik bu manastırlardan birinde ikamet etmiştir. Kilisenin gerek dinî gerek idari kararlarının alındığı Sen-Sinod'un üyeleri çoğunlukla manastır reislerinden oluşmuştur. Tur Abdin ve çevresinde monastik hayatın en canlı olduğu dönemler IV. - VII. yüzyıllar arasındadır. Doğu Hristiyanlığı'nı temsil eden şöhretli din adamlarından, ilahiyatçılardan, filozoflardan ve mistiklerden önemli bir bölümü bu dönemde bu bölgede yetişmişlerdir. Onlar, eserlerinde monastik hayatın temel kurallarını ve ruhaniyetin felsefi temellerini tespit ve izah etmişlerdir. Tur Abdin Bölgesi'nde Mor Evgin'le başlayıp ilerleyen süreçte sistemli bir yapıya kavuşan monastik hayat (Atiya, 2005: 291), zamanla öylesine kök salmıştır ki, V. yüzyılda bölgedeki manastırlarda 90 bin keşişin yaşadığı rivayet edilmektedir (Downey, 1961: 481 vd; Lorey, 1963: 131 vd; Hannah, 1925: 48 vd.). Bu açıdan bakıldığında manastır müessesesi, basit şekilde ve sadece dünyadan el etek çekmiş insanların ikametgâhları olarak değerlendirilemez. Zira bu kurumun Doğu Hristiyanlığındaki anlam ve önemi göründüğünden ve tahmin edildiğinden çok daha fazladır.

Tur Abdin Bölgesi, Süryanice konuşan Hristiyanların eski tarihlerden itibaren yoğun yaşadıkları bir coğrafi sahadır. Bu nedenle bu bölgede Mor Evgin’le başlayıp zamanla gelişen münzevi yaşam, aslında büyük ölçüde Süryani Hristiyanlığı çerçevesinde yorumlanmaktadır. Bu doğrultuda, Süryani Hristiyanlığı özelinde münzevi yaşamın başlangıcı ve geçmişi, bilhassa Batı'da birçok araştırmaya konu olmuş ise de hâlâ aydınlatılamamış birçok boyut ihtiva etmektedir. Üstelik Türkçe literatürde de bu konuda ilgi ve bilgi eksikliği göze 
çarpmaktadır. Buradan hareketle bu makale, Hristiyan münzevi yaşamını özellikle Süryani Hristiyanlığı ve dolayısıyla Tur Abdin Bölgesi özelinde ana hatlarıyla ve giriş mahiyetinde betimleme amacı taşımaktadır. Bu amaçla önce, "Manastır Hayatının Kuralları”, “Manastırlarda Günlük Hayat ve İbadetler”, “Manastırların Müntesipleri” ve "Dini Çekişmelerde Manastırların Oynadığı Roller” gibi alt başlıklar altında Tur Abdin Bölgesi'ndeki münzevi yaşamın çerçevesi genel hatlarla çizilmektedir. Bir sonraki aşamada, bölgede manastır yaşamını başlatan ya da tetikleyen bir dini yapı olarak taşıdığı önem nedeniyle Mor Evgin Manastırı tarihi ve mimari açılardan özetle tasvir edilmektedir. Söz konusu manastıra dair anlatım, makalenin son kısmını oluşturan görsel materyaller ile de desteklenmektedir.

\section{Tur Abdin Bölgesi'nde Münzevi Yaşam}

Mistisizm, münzevilik ya da tasavvufi anlayış gibi kavramlarla da tanımlanan veya bu kavramlarla yakın ilişkisi bulunan "monastisizm”, -sözcüğün Yunanca kökeni olan monos ${ }^{2}$ (“yalnız", “tek”)- ifadesinden de anlaşılacağı üzere, kalabalıklardan uzaklaşan, huzuru ve kurtuluşu yalnızlıkta arayan herhangi bir insanın dünyevi hazlardan vazgeçip tamamıyla ruhsal/uhrevi âleme yönelmesidir. Münzevi yaşam, Hristiyanlığın öncesinde de sonrasında da farklı dinlerde başka başka formlarıyla var olmuştur. Ancak genel itibariyle münzevi yaşamı benimseyen her birey için birkaç temel aşamadan geçmek zaruri görülmüştür.

Talip, işe kendi varlığını inkâr ederek başlamalıdır. Hristiyan ve Süryani mistik anlayışlarında bu temel kural, İncil metinlerinde İsa-Mesih'e atfedilen şu söze dayandırılır: "Her kim benim ardımdan gelmek isterse, kendisini inkâr etsin" (Luka, IX, 23). İsa'nın burada, bireyin kendi varlığını da tıpkı dünya ve dünya hayatı gibi bir hiç kabul etmesi gerektiği mesajını verdiği düşünülmektedir.

İkinci olarak kişinin bedenine haz veren tüm arzu ve isteklerden kaçınması gerekir. Yemek ve cinsellik bunların başında gelir. Birey, sevdiği ne kadar yiyecek varsa, bunları yemekten kaçınır. Bekârlık, iffetin olmazsa olmaz şartıdır. Nitekim münzevilerin hayatlarını anlatan eserlerde bu konu azizlerin ermişliğinin temel ilkesi olarak sunulmaktadır. Özellikle Batı'da Tertullianus (ö.240?), Doğu'da ise Afrahat (ö.345?) ve Nyssa Piskoposu Gregorios (ö.395) ${ }^{3}$ bu konu üzerinde şiddetle durmuşlardır. ${ }^{4}$ Bu anlayış IV. yüzyıldan itibaren daha da katılaşarak genel

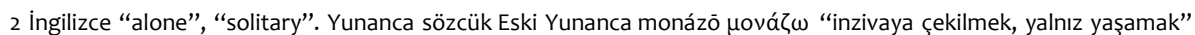
fiilinden türetilmiştir. Bu sözcük Eski Yunanca mónos $\mu$ óvoৎ “tek, yalnız” sözcüğünden türetilmiştir. Henry George Liddell, Robert Scott, An Intermediate Greek-English Lexicon, www.perseus.tufts.edu 02.02.2021 3 Meşhur Kilise Babası Kapadokyalı Basil'in kardeşidir. 372-95 yılları arasında Nyssa metropolitliği yaptı.

4 Bu konuda geniş bilgi için bkz. Archimandrite George, Theosis the True Purpose of Human Life', Abbot of the Monastery St. Gregorios- Mount Athos,2006; Afrahat, Demostrations VI. NPNF, Vol. XIII. (ed. Philip Schaff and Henry Wace) The Cristian Literature Company, Newyork, 1890; Tertullian, On Exhortation to Chastity, Translated by S. Thelwall, In The Ante-Nicene Fathers, Vol.4, (ed.) Alexander Roberts and James Donaldson, Edinburgh 1873
} 
bir ilke hâline gelmiş ve kilisenin yönetim kadrolarında görev alacak ruhanilerde aranacak temel şart olarak kabul edilmiştir.

Bir zahit için asketik yaşamın amacının, dünya ve dünyadaki her şeyin boş ve geçici olduğu bilinciyle, ruhu arındırıp ebedî gerçekliğe ulaşmak olduğu fikri hiçbir zaman unutulmamalıdır. Zahit, bedenine sadece haz veren gıdalardan kaçınmakla da yetinmez, manevi haz veren şeylerden de kaçınır. Örneğin vücuduna rahatlık veren ve onu güzel gösteren her türlü giyim ve kuşamdan kaçınır. Bu nedenle giysi, zahit için sadece basit bir örtünme aracı olmalıdır. Vücuda rahatlık ve haz veren, ${ }^{5}$ nefsi gururlandıran kalite ve nitelikte olmamalıdır. Zahidin elbisesi, kendisi için bir "iffet kalkanı" olmalıdır. Karşı cinsin duygularını cezbedecek, günaha giden yolda kalbi vesveseye düşürecek evsafta olmamalıdır. ${ }^{6}$ Ruhbanların elbiselerini tamamlayan sembol ise, Yahya'dan kalan zünnar (kuşak) dır. ${ }^{7}$ Tüm Ortodoks dünyasında, ruhanilerin kıyafetleri siyahtır. Bir rahibin başı açık gezmesi uygun değildir. Rahibelerin de kıyafetleri siyahtır. Tesettür kesinlikle uyulması gereken bir kuraldır. El ve yüz dışındaki tüm uzuvlar kapatılır. Rahibeler hiçbir ziynet eşyası takmazlar.

Tarih boyunca Süryani toplumunda tesettüre hem ruhani dünyaya intisap edenler, hem de sivil hayat yaşayan kadınlar titizlikle uymuşlardır. Bunun için kilise son derece sert kurallar da koymuştur. Örneğin Urfa piskoposu Rabbula (ö.435?) tesettüre uymayan, başını örtmeyen kadınları hastaneye dahi kabul etmemiş, tedavilerinin yapılmasını yasaklamıştır. ${ }^{8}$ Bu anlayış uyarınca kadınlarla erkeklerin zaruret dışında birbirleriyle konuşmaları da hoş görülmemiştir.

Zahit, üçüncü aşamada "yalnızlık” ve "inziva” safhasına girer (Wishart, 1990: 20 vd.). Bu nedenle manastırlar, yerleşim yerlerinden uzak, ulaşılması zor, sarp kayalıkların üzerine inşa edilmişlerdir. Bu, sadece Tur Abdin bölgesine has bir durum değildir. Neredeyse tüm Hristiyan dünyasının mistik hayatında bu anlayış geçerlidir.

\section{Manastır Hayatının Kuralları}

Manastır yaşamında, aynı inancı, düşünceyi ve hedefleri paylaşan insanların toplu hâlde yaşamaları ilkesi esastır. Bilindiği gibi insanların toplu yaşadıkları yerlerde, düzeni sağlamak için kurallara ihtiyaç duyulmuştur. Bu kurallar tarihsel süreçte gelişerek kanunları ve yönetmelikleri oluşturmuşlardır.

\footnotetext{
5 Doğu Hristiyan mistikler bu hususta Hz. Yahya'yı örnek (Yahya'nın deve tüyünden giysisi... Matta, III, 4) almışlardır.

6 Bu konuda elbise-zina ilişkisi hakkında tahliller için ed-Daskaliyye, ev Te’alimu’r Rusûl, 1940 (neşr. Hafız Davud), Mısır, çeşitli bölümlerine bakınız.

7 Bkz. Matta, III, 4.

8 Bkz. Şükran Yaşar, "Şehrin Sosyo - Ekonomik Yapısı”, Edessa'dan Urfa'ya I, Ankara-2007 (Ed. Mehmet Çelik), s. 527 - 528. ; Rabbula'nın bu konu hakkındaki kuralları için bkz: A.Vööbus, History of Ascetism in the Syrian Orient, 1958
} 
Bu nedenle manastırlarda da son derece düzenli ve disiplinli bir yaşam tarzı egemen kılınmıştır.

Her şeyden önce, her ne kadar ruhani hayat ideali ve buna bağlı beklentiler öncelikli ise de, manastırların aslında birer eğitim kurumu oldukları göz önünde bulundurulmalıdır. Bu çerçevede buralarda ilk öğretilen değer, kayıtsız - şartsız itaattir. Bu itaat, dini bazı ilkeler ve söylemlerle sağlandıktan ${ }^{9}$ sonra, ruhanilerin bedenlerinde taşıdıkları ruhsal hastalıklarla mücadele edilmesi gerekli görülmüştür. Bu hastalıkların en önemlileri kibir, gurur, gevezelik, uyku ve tembellik, oburluk ve yaşam şartlarından şikâyet etmektir. Tüm bu evrelerin sonrasında manastırlarda disiplini sağlamak çok daha kolay olmuştur.

Manastırlarda, işlenen suça göre, sözlü uyarmadan fiilen manastırdan uzaklaştırmaya kadar çeşitli disiplin cezaları uygulanmıştır. Bu ceza ve uygulamalar manastır reisinin bilgisi dahilinde olur. Sanık veya sanıklar sorgulanırken veya şahitler dinlenirken âdalete titizlikle riayet edilmesi, ${ }^{10}$ şahsi husumet ve tarafgirlikten kaçınılması ${ }^{11}$ ve eğer işledikleri suç dinî ve itikadî değilse ${ }^{12}$ sanıklara şefkat ve merhametle yaklaşılması esastır. Zira temelde tövbe ve pişmanlığı sağlamak ve sanığa yeni bir şans tanımak amaçlanmaktadır. ${ }^{13}$ Manastırlarda, cezalandırılan sanığı utandırmak, küçük düşürmek gibi psikolojik yöntemler en fazla başvurulan ceza yöntemleridir. Örneğin sanığın ayine katılımının önlenmesi, yemekhanede toplu yemek yenirken sanığı yemek bitene kadar ayakta bekletme, zûnnarını bağlamasını yasaklama, hücre hapsi, konuşma boykotuna tabi tutma, bunlar arasındadır. ${ }^{14}$ Ancak sanık, manastırın düzenini bozacak, başkalarını kötü yönde etkileyecek tavır ve fiillere devam ediyor ve ısrarla ıslah olmuyorsa, vücudu korumak için hastalıklı uzvu kesip atmak nasıl kaçınılmazsa (Basil, Long Rules, 1950: 46 vd.) o da manastırdan uzaklaştırılmalıdır.

Her ne kadar manastırların disiplin kuralları Kitab-ı Mukaddes'e atıfla oluşturulmuşsa da, uygulamalar daha ziyade manastır reislerinin kişilikleri ve anlayışları çizgisinde oluşturulmuştur.

Orta Çağ'da Doğu Hristiyanlığında erkek ve kadınlara mahsus ayrı ayrı manastırlar bulunurdu. Ancak zamanla kadın ruhanîlerin sayısı azaldıkça bu müstakil manastırlar kapanmıştır. Bunun yerine kadınlara, erkek manastırlarında onlar için uygun yerler tahsis edilmeye başlanmıştır. Süryaniler açısından bakıldığında, günümüzde Mor Gabriel ve Deyrü'z-Zaferan manastırlarında

\footnotetext{
9 İtaat ve temel ilkeler için bkz. ed-Daskaliyye ev Te'alimu'r Rusûl, s. 53 vd.

10 Bu konuda Kilise'nin anlayışı Kitab-ı Mukaddes'te yer alan şu örneklere ve emirlere dayanır: Matta V/9, VII/1, XVIII/16, XXVI/59-61; Danyal I; I. Krallar XXI/1-13; Resullerin İşleri VI/11-15... Genel bilgi için bkz. ed-Daskaliyye, Böl. VIII.

11 ed-Daskaliyye, Böl. VIII.

12 Dinî ve itikadî ise aforoz edilerek, manastırdan atılır.

13 ed-Daskaliyye, Böl. VIII.

14 Bu konuda Pachomius Kuralları için bkz. Bart D. Ehrman - Andrew S. Jacobs, Christianity in Late Antiquity (300450),Oxford Üniversitesi Yay., 2004, s. 131-137; Basil, Long Rules için bkz. Monica Wagner, Saint Basil - Ascetical Works, The Catholic Universty, America Press, Washington - 1950, 27-28, 46-53.
} 
rahibelere ait müstakil birimler mevcuttur. Rahibelerin bölümlerinde kurallar daha da serttir ve bunlara titizlikle uyulur. Başrahibe, bu konuda tam yetkilidir ve manastır reisine karşı sorumludur. Erkeklerin, rahibelere ait bölümlere girmeleri yasaktır.

\section{Manastırlarda Günlük Hayat ve İbadetler}

Manastırlar, toplu yaşama mekânlarıdır. Manastır sakinlerinin asıl amaçları, dünyadan el-etek çekmek; bedenî, nefsi duyguları öldürüp, ruhu yücelterek hakikate ulaşmaktır. Ancak bir de hayatın kaçınılmaz gerçekleri de vardır. Bunların başında yeme-içme, giyinme, barınma gibi ihtiyaçlar gelir. Ayrıca, yüzlerce hatta binlerce ruhbanın yaşadığı manastırlarda, insanları "bir şeylerle meşgul etmek" de gerekmektedir. Bu meşguliyet, hem düzenin sağlanması, hem de ruhanilerdeki ruhsal yapının sağlığı için gerekli görülmüştür.

Manastırlarda çalışma hayatının sınırları olarak günlük temel ihtiyaçlarını asgari düzeyde sağlayan ve keşişleri meşgul eden bir anlayış benimsenmiştir. Çalışma sürecinde ruhaniler iki temel kuralla yükümlüdürler. Birinci kural, işi savsaklamamak, işten kaçmamaktır. İkincisi ise işe aşırı düşkünlük gösterip işi "dinî hayatın önüne" geçirmemektir. Manastırlarda çalışma alanlarını ve ilkelerini, manastır reisleri belirler. Bu ilkeler, bölgelere ve manastırlara göre, zaman ve zemine göre, yapılan işlerin mahiyetlerine göre değişir. Süryani dünyasındaki manastırların temel kuralları, bir zamanlar Afrahat ${ }^{15}$ ve Rabbula (J.Thomas, 2000: 39-40 $)^{16}$ tarafından konulmuş ilkelere dayanmaktadır.

Süryani manastırlarında ruhanileri meşgul etmek için yüzyıllardır sürdürülen bir gelenek de kitap istinsahıdır. Burada amaç, ruhanileri meşgul etmek kadar, yazılarının güzelleşmesini ve okuma-yazma becerilerini geliştirmektir. Bu nedenle Süryani manastırlarında, kilise babalarının kaleme aldıkları birçok eserin onlarca yazma nüshalarına rastlanmaktadır.

Manastır hayatının en önemli konularından birisi de yemektir. Bu hayatı tercih edenlerin amacı, bedeni, dünyevî haz ve zevklerden kurtararak, daha açık bir ifade ile "nefsi öldürerek", ruhun kurtuluşunu sağlamaktır. Yemek, sadece hayatta kalabilecek kadar yenir. Bedene güç, kuvvet ve zevk veren yiyeceklerden, başta hayvanî gıdalar ile şarap olmak üzere, kaçınılır. Yemek esnasında sessizlik esastır. Başrahibin yaptığı dua ile yemeğe başlanır. Eskiden rahipler gruplar hâlinde aynı kaptan yemek yerlerdi. Bu nedenle açgözlülük etmek, hızlı yemek hoş karşılanmazdı. Yemek bitiminde, başrahip kalkmadan kimse yemekhaneyi terk etmez. Toplu yemeğin dışında, daha sıkı perhiz yapan asketiklere yiyecekleri hususunda daha titiz davranılır; onlara, genel olarak bir parça kuru ekmek ve bir miktar tuz verilir.

15 Bkz: Afrahat, Demonstrations VI. NPNF, Vol. XIII, 1890

16 Geniş bilgi için bkz: A.Vööbus, History of Ascetism in the Syrian Orient,1958 
Manastırların en önemli işlevi dünyadan el-etek çeken insanların kendilerini yirmi dört saat ibadete vermeleridir. Ruhani, bir an bile ibadetten gafil olmamalıdır. Toplu olarak icra edilen ibadetlerin başında Slutho (Sıloto), yani namaz gelir. Süryani Kilisesi'nde sabah, kuşluk, öğlen, ikindi, akşam, yatsı ve gece yarısı olmak üzere yedi vakit namaz vardır. Bunlardan sabah, öğlen ve akşam namazları cemaatle kilisede icra edilir. Geriye kalan dört vakti ise ruhaniler ferdi olarak icra ederler. Kadınlar, namazda erkeklerin arkasında saf tutarlar. Süryani Kilisesi'nde azizlere adanan çok sayıda kutsal gün ve gece ile oruç uygulaması da vardır. Bu kutsal gün ve geceler ayin yapmak suretiyle kutlanır. Oruç, bir nevi perhizdir; yani oruçlu olan mümin hayvani gıdalar tüketemez, ama oruçlu iken her türlü bitkisel gıdayı alabilir. ${ }^{17}$

Manastırlarda iki defin mekânı bulunmaktadır. Bunlardan biri manastırın içinde yer alır ki bu bölüme Beth Qadișe (Azizler Evi) denir. Buraya sadece azizler, manastır reisleri, piskopos, metropolit ve patrikler gömülür. Diğer mezarlık manastırın bahçesinde yer alır. Buraya da manastırda yaşayan rahip, rahibe ve öğrencilerden vefat edenler gömülür.

\section{Manastırların Müntesipleri}

Manastırlar açısından temel insan (yani ruhani) kaynağı, aileleri tarafından henüz küçük yaşta ruhban olarak yetiştirilmeleri için manastırlara verilen kız ve erkek çocuklarıdır ki bunlar, iki gruba ayrılırlar. Birinci grup, ruhbanlık eğitimi almaları için manastırlara teslim edilmiş çocuklardır. Bu çocuklar, temel düzeyde eğitim aldıktan sonra isterlerse ruhban olarak takdis edilirler, isterlerse manastırdan ayrılırlar. İkinci grup ise ailelerince manastırlara vakfedilen çocuklardır. Süryaniler arasındaki geleneğe göre, beş çocuğu olan bir aile bu çocuklardan birini manastıra vakfeder.Bu çocuk artık manastıra ait olur.

Manastırların bir başka insan kaynağı, mizaçları itibariyle ruhanî hayata meyilli olanlardır. Onlar, huzurlu gördükleri manevi hayatı yaşamak için manastırlara intisap eden kimselerdir.

Bənay Qəyome (Ahdin Çocukları) ve Bənot Qəyome (Ahdin Kızları) ise manastırların ve ruhban sınıfının en önemli kaynaklarıdır. Bunlar resmen takdis edilmeyen, ancak sıkı şekilde oruç tutan, iffetlerini koruyan, züht ve takvaya önem veren, bekârlığı esas alan erkek ve kadın topluluklarıdır. Onların, resmen takdis edilmiş ruhbanlardan tek farkları, "yoksulluk yemini” etmemiş olmaları, kendi sahip oldukları malların tasarruf haklarını kullanabilmelerdir. ${ }^{18}$ Geçmişte yaygın olduğu görülen bu kurumsal yapı, bugün için artık işlevsizdir.

\footnotetext{
17 Konunun detayları için merak edenler, Nihat Durak'ın Süryani Ortodoks Kilisesi'nde i̇badet, İstanbul-2011, adlı çalışmasına bakabilirler.

18 Geniş bilgi için bkz. Şükran Yaşar, "Şehrin Sosyo-Ekonomik Yapısı”, I.s.503-504, dipnot: 2042
} 
Yukarıdaki verilere ilaveten, sosyal yapının daha farklı olduğu eski dönemlerde tembeller ve miskinler, ağır işlerde çalışanlar ve ayrıca köleler, manastırlar için önemli insan kaynaklarını teşkil etmişlerdir. Zira yönetici ve seçkin sınıfların altında ezilen bu insanlar, manastırları hem bir kaçış hem de bedenlerini ve ruhlarını dinlendirebilecekleri mekânlar olarak görmüşlerdir. Köleler, hiç şüphe yok ki bu bağlamda üzerinde bilhassa durulması gereken bir sınıfı oluşturmuşlardır.

İlk ve Orta Çağ’ın en ağır yükünü taşıyan insan sınıfı hiç şüphesiz kölelerdi. Manastır hayatına intisap etmek isteyen köle hakkında önce gerekli soruşturmalar yapılmıştır. Efendisi kötü bir adamsa, dindar biri değilse ve kölede de müspet özellikler varsa, manastıra kabul edilmiştir. Hatta köle Hristiyan iken sahibinin başka bir dine mensubiyeti veya sahibinin köleye İsa-Mesih'in emir ve nehiylerini ihlal eden emirler veriyor ve işler yaptırıyor olması, bu kölenin manastıra derhal kabul edilmesini kilisevî bir zorunluluk hâline getirirdi (Basil, Long Rules, 1950: 11). Manastırların köleler hakkındaki uygulamaları genel çizgileriyle bu şekilde olmakla beraber, zaman zaman kölelerin efendilerine bağlılıklarını zayıflatan ve onları efendilerinden ayrılarak gelip manastıra intisap etmelerini teşvik eden uygulamalara da rastlanmıştır. ${ }^{19}$ Zamanla, laik kesimler tarafından bu konuda şikâyetler hem kiliseye, hem idari makamlara yapılmış olmalı ki, konu 451 Kadıköy Konsili'nde gündeme alınmış ve efendisinin müsaadesi alınmadan, hiçbir kölenin, sebebi ne olursa olsun manastıra alınmaması kabul edilmiștir ( Hefele, 1896: 389 vd.).

Roma İmparatorluğu'nda köylülerin durumu da pek parlak sayılmazdı. Toprağa bağlı bu kesimlerin farklı zamanlarda değişkenlik gösteren birçok sorunla karşı karşıya kaldıkları bilinmektedir. Söz gelimi, salgın hastalıklar, doğal afetler, kıtlıklar, ağır vergiler, bilhassa bu kesimler üzerinde olumsuz tesirler yaratmıştır. Bu açıdan denilebilir ki, hayatın bütün bu olumsuz etkenlerinin faturasını en ağır biçimde ödeyen ve elinde-avucunda bir şey kalmayan bu insanlar için de sığınılacak tek yer manastırlar olmuştur.

Yukarıda da görüldüğü gibi sosyal ve iktisadi yapı başta olmak üzere birçok faktör, manastırların ihtiyaç duydukları insan kitlesinin temin edilmesi noktasında önem taşımışlardır. Bunlara ilaveten Roma İmparatoru Constantinus (ö.337) dönemindeki bazı düzenlemeleri de hatırlamak gerekir. Bilindiği gibi Constantinus, hem 313'teki Milano Fermanı'nda hem de sonrası süreçte Kilise 'ye ekonomik, sosyal ve hukuki açılardan imtiyazlar bahşetmiştir (Çelik, 1999: 16 vd.). Bunlardan biri de "askeri imtiyaz" başlığı altında incelenmektedir. Zira söz konusu düzenlemeyle, din adamları, keșişler ve manastırlarda ruhani hayata intisap edenler askerlikten muaf tutulmuşlardır (Vasiliev, 1943: 63; Bihlmeyer ve Tuchle, 1972: 62). Bu imtiyazın bazı bireyler ya da kesimlerce zaman zaman

19340 yılında Gangra (Çankırı)'da toplanan Sinod'da görüşülen konular arasında kölelerin durumu da vardır. Konsilde 20 kanun maddesi kabul edilmiştir. Bunlardan biri de kölelerle ilgilidir. Bkz. Joseph Hefele, A History of Consils of the Church, Edinburg, 1896, Vol. II, s.325 vd. 
istismar edilmesi, zamanla imparatorların ve devlet adamlarının dikkatini çekmiştir. Nitekim bazı imparatorların, (kamusal görevlerden ve askerlikten kaçmak için) manastırlara sığınıp ruhbanlığa intisap edenler hakkında onların intisaplarının iptal edilip manastırlardan çıkarılmaları için emirnameler kaleme aldığı bilinmektedir (Talbot, 1999: 164).

Dinî veya herhangi başka bir nedenle evini ve eşini terk edip manastıra intisap etmek isteyen evli kimseler de olmuştur. Ancak her adayda olduğu gibi onlar hakkında da öncelikle detaylı bir inceleme yapılır, durumları hakkında müspet kanaat oluşursa manastıra kabul edilirlerdi. Erkek, erkek manastırına, kadın, kadın manastırına gönderilirdi. Bu safhadan sonra böyle bir çiftin artık beraberliği söz konusu olamazdı. Şayet eşlerden sadece biri müracaat etmişse, diğer eşin mutlaka rıza göstermesi gerekirdi. Eş rıza göstermezse, aday olan diğer eş manastıra kabul edilmezdi. Ancak eşlerden biri zalim ve kötü idiyse veya dinî hususta yanlışları varsa, dindar ve mazlum eşi korumak da Kilise'nin göreviydi. Bu durumda eşin rızasına bakılmaz ve bu kabul şahitler huzurunda yapılırdı (Basil, Long Rules: 12).

Hayata küsenler ve bezginler, günahkârlar ve tövbekârlar, dullar, yetimler, öksüzler ve kimsesizler de manastır ahalisinin ciddi bir bölümünü oluştururdu. Manastır yönetimleri, bu tür insanları da ince eleyip sık dokuyarak gerekli incelemeden geçirdikten sonra, uygun gördüklerini manastıra kabul ederlerdi.

Kan davası ve düşman korkusuyla yaşayıp manastıra sığınanlar da soruşturulur, gerçekten suçsuz olduğuna kanaat getirilirse, ayrıca dinî inançları ve yaşantısı da uygunsa, manastıra kabul edilirlerdi.

\section{Dini Çekişmelerde Manastırların Oynadığı Rol}

Hristiyanlık, 325'teki İznik Konsili'yle birlikte geniş çaplı devlet desteği elde edip devlet çarkı içinde yapısal kimliğe kavuşunca (Çelik, 1999: 13 vd.), Kiliseler arasında yetki ve hâkimiyet çekişmesi ön plana çıkmıştır. Bu çekişmeler, öncelikle İznik Konsili'nde diğer kiliseler üzerinde yetkili ve üstün bir statüye kavuşturulan Roma, Antakya ve İskenderiye Kiliseleri arasında; bir sonraki aşamada 381 İstanbul Konsili'yle birlikte aynı imtiyazı elde eden Konstantinopolis Kilisesi'nin de iştirakiyle sürmüştür. Hristiyanlık dünyasını derinden etkileyen bu çekişmeler, teolojik ihtilaflar üzerinden yürütülmüştür (Çelik, 1987: 98vd.; Çelik, 200o: 20vd.).

İşte bu büyük kilise merkezleri arasında ortaya çıkan söz konusu çekişmelerin motor gücünü Manastırlarda yaşayan keşişler oluşturmuşlardır. Keşişler, V. yüzyıl başlarından itibaren Mısır gibi belli başlı eyaletlerde organize milis güç hâline gelmişlerdir. Bu bağlamda farklı kilise merkezlerinde kendi kilise teşkilatları ve teolojik anlayışları temelinde organize olan bu keşiş ordularının, imparatorluğun dinî siyaseti üzerinde de yer yer etkin roller üstlendikleri anlaşılmaktadır. Örneğin, İskenderiye Patriği Kurilos'un 431 Efes Konsili'nde, 
İmparatorun başkent (Konstantinopolis) patriği Nastoryus'u aforoz edip yerine kendi kâtibini ataması ve tüm bunları imparatora onaylatarak (Çelik,1999: 31 vd.) bir fermanla Hristiyan dünyasına ilan ettirmesi, arkasındaki keşiş ordusundan aldığı bu güce dayanmaktadır. Nitekim başkentin iki patriğinin ardı ardına aforoza uğramaları, ${ }^{20}$ hem Başkent Kilisesi'ni, hem Başkent halkını ve hem de İmparator Marcianus'u (450-457) yeni arayışlara ve hatta İskenderiye Kilisesi'ne karşı intikam ve rövanş hissiyatına yöneltmiştir. İmparator II. Theodosius Mısır'daki bu keşiş sürülerinden çekindiği için bütün bunları sineye çekmişti. Marcian ise her şeyi göze alıp bir konsil topladı. Kadıköy'de toplanan Konsil (451) işte bu arka plana dayanmaktadır; İmparator bu Konsilde İskenderiye Patriği Dioscorus'u aforoz ettirerek sürgüne yollamış, yerine Proterius adında bir piskoposu Patrik olarak İskenderiye'ye göndermiştir (Çelik, 2000: $91 \mathrm{vd}$.).

$\mathrm{Bu}$ sürecin devamına bakıldığında Mısırlı keşişlerin etkin rolleri izlenmektedir. Kadıköy Konsili kararlarını ve Dioscorus'un aforoz edilmesini reddeden fanatik Mısırlı keşişler, şehre askeri birlikler eşliğinde gelebilen yeni Patrik Proterius'a karşı nümayişlere ve gösterilere başlamışlardır. Kısa sürede çatışmalara dönüşen bu gösterilerde yirmi dört bin kişinin hayatını kaybettiği rivayet edilmektedir ki, bunların önemli bir kısmı keşişlerdir. Olaylar zaman zaman yatışsa da buna rağmen sükûnet tam olarak sağlanamamış, nihayet 457 yılında Patrik Proterius bağnaz keşişler tarafından hem de Kilise 'de bir ayin esnasında linç edilerek katledilmiştir. ${ }^{21}$

Roma İmparatorluğu'nun bilhassa Hristiyan nüfusun yoğun yaşadığı diğer bazı bölgelerine bakıldığında da buna benzer tablolar görmek mümkündür. Söz gelimi, Süryani manastırlarının yoğun olduğu Suriye ve Doğu Anadolu bölgelerinde ya da Filistin'de de Kadıköy Konsili karşıtı keşişler imparatorluk yönetimince bu Konsil sonrasında izlenmeye başlanan din siyasetinin başlıca muhalifleri olmuşlardır. Nitekim VI. yüzyıldan itibaren bir literatür disiplini olarak gelişen historiyografi karakterli Süryanice metinler, önceleri Kadıköy Konsili'ne ısrarla karşı çıkan, sonrasında ise İskenderiyeli Kurilos (ö.444) ve Antakyalı Severus (ö.538) gibi önemli ilahiyatçıların kristolojik pozisyonlarını benimseyerek konsil karşıtı duruşlarını daha sertleştiren Miafizit keşişlerin sürgün edilmelerine ve hatta yer yer öldürülmelerine dair anlatılar içermektedir. ${ }^{22}$ Miafizit keşişlerin bu mücadeleleri, VI. yüzyılla birlikte Süryanice litürjiyi esas alan ayrı kilise hiyerarşilerinin doğuşuna zemin hazırlamıştır ki, bu örnek bile tek başına keşişlerin dini çekişmelerde ne denli önemli roller üstlendiklerini kanıtlamaktadır.

20 Nitekim İskenderiye patriği Dioscorus, selefi Kurilos gibi 449 II. Efes konsilinde başkent patriği Flavian'ı aforoz ettiriyordu.

21 Bkz. Frend, The Rise of Monophysite Movement: Chapters in the History of the Church in the Fifth and Sixth Centuries, Cambridge Üniversitesi Yay.,1979, 155; Dovernik, The Idea of Apostocility in Byzantium and the Legend of the Apostle Andrew, Harvard Üniversitesi Yay., Cambridge, 1958, 104vd.; G. Kirg, Middle East From Rise of Islam, 9vd.

22 Bkz. Çelik, Süryani Kilisesi, I, 205vd. 
Roma İmparatorluğu'nda (bilhassa Geç Antikçağ'da) itikadî saiklerle keşişlerin askerî birliklere karşı giriştikleri eylemlerde binlerce keşiş hayatını kaybetmiştir. Ancak onlar, dinî fanatizm ile mücadeleden yılmamışlar ve geri adım atmamışlardır. Çünkü onlar, bu mücadeleleri İsa-Mesih adına verdiklerine inanmışlar ve şehit olarak cennete gideceklerini düşünmüşlerdir. Kadıköy Konsili yanlısı imparatorluk merkezinin özellikle Miafizit görüşlü keşişlerle mücadeleleri bağlamında İmparator I. Iustinus (518-527) ${ }^{23}$ (Atiya, 2005: 179 vd.) ve lustinianus (527-565) dönemleri (Çelik, 2000: 61 vd.) bu açıdan dikkat çekicidir. Zira bu iki imparator döneminde Miafizit görüşlü keşişler kovuşturmalara uğramışlardır.

Buna karşın imparatorluk yönetiminin Miafizitleri memnun edecek bir din siyaseti izlediği İmparator Zenon (474-491) ya da Anastasios (491-518) dönemlerinde ise, bu kez de Kadıköy Konsili yanlısı Diofizit görüşlü keşişlerin sert muhalefetlerine rastlanmaktadır. Bilindiği gibi bu muhalefet, Zenon döneminde Hristiyanlık dünyasında Akakios Skhisması denilen uzun süreli bir bölünmeye, Anastasios döneminde ise bizzat başkent sokaklarında ciddi ve kanlı nümayişlere yol açmıştır.

Fanatik keşişlerin etkin rolleri sonraki yüzyıllarda da önemli ölçüde sürmüştür. Bizans İmparatorluğu tarihinde VIII. yüzyıla tarihlenen İkonoklast dönem bu bağlamda dikkat çekici örnekler arasındadır. Zira bilhassa fanatik keşişlerin ikonalara bağlı olmaları, ikonoklast reformun başarısızlığa uğrama nedenleri arasında gösterilmektedir (Çelik, 1999: 73 vd.).

Keşişler, elbette sadece kiliseler arası mücadelelerde etkin bir güç olarak kullanılmamışlardır. Onlar, zaman zaman devletin çıkarları yönünde de kullanılmışlardır. Keşiş ordularının gücünü fark eden bazı imparatorlar, Manastırın yönetimini kiliselerden alıp bizzat kendilerine bağlamışlardır (Ostrogorsky, 1981: 174 vd.). Nitekim Bizans yönetimi, kuzeyden gelen Slav tehlikesini bu keşişler ordusunu organize ederek yani onların yardımıyla Slavları Hristiyanlaştırmak suretiyle önlemiştir (Çelik, 1999: 134 vd.).

Sonuç olarak, bir zamanlar miskin bir hayat gayesiyle yola çıkan ve nefislerini öldürmek amacıyla dünyadan el etek çeken keşişler, zamanla dünyevi amaçlar çizgisinde organize edilmişler ve kiliseler arasında yaşanan statü ve nüfuz mücadelelerinde kullanılmışlardır. Bu olgu, çeşitli kilise merkezlerine bağlı keşişlerin başka kilise merkezleri ve hatta devlet güçleriyle mücadele etmeye başlamaları kadar, bizzat kendi kiliselerinin yönetimlerinde de söz sahibi olma mücadelesine kalkışmalarına yol açmıştır. Nitekim VI. yüzyıldan itibaren gerek manastır yönetimlerinin oluşmasında ve gerekse de Piskopos ve Patrik seçimlerinde bu keşişlerin oldukça etkin oldukları gözlenmektedir. Manastırlar

23 Geniş bilgi için bkz. A. A. Vasiliev, Justin the First: An Introduction to the Epoch Justinian the Great, Dumbarton Oaks Studies I, Cambridge Mass-1950. 
artık bu tarihten itibaren kendi kiliselerine hem teolojik, hem de idari açıdan yön veren merkezlerdir. ${ }^{24}$

\section{Mor Evgin Manastırı}

İngiliz seyyah Gertrude Bell (1868-1926), Mor Evgin Manastırı için kaleme aldığı yazıya şu cümle ile başlamaktadır: "Şimdiye kadar Tur Abdin'de gezdiğim en çarpıcı manastır Mor Evgin'dir” (1982: 3) (Resim - 2). Yüzyılların tahribatı Mor Evgin Manastırı'nı fazlasıyla hırpalamışsa da, bu eski yapı bugün bile hâlâ İzlo (Bakok) Dağı'nın güney tarafında ovaya salınmış bir abide gibi durmaktadır. Manastır, çaprazvari uzanan bir haçın yukarıya kaldırılmış hâlini andırmakta (Resim-3), muhteşem Mezopotamya Ovası'nı âdeta bir kartalı andıran bakışlarıyla taramaktadır. Manastır çevresinde manevi hava egemendir, manastırın bazı kısımları kayalara oyulmuş, ön tarafları uçurumla burun buruna duran münzevi mağaralarının âdeta eski sakinlerinin huşu içindeki ruhaniyetlerini yüzyıllar ötesinden hissetmek mümkündür.

Mor Evgin Manastırı, Nusaybin-Şırnak karayolu üzerinde bulunan Girmeli Beldesi'nin 8 km. kuzeyinde, Mezopotamya ovasına bakan İzlo Dağları'nın sarp yamaçları üzerine kurulmuş (Resim-4) ve ovaya tamamen hâkim bir şekilde konuşlandırılmıştır (Resim-5). Günümüzde yapılan $13 \mathrm{~km}$ 'lik yol sayesinde manastıra rahatlıkla ulaşılabilmektedir. Manastır topluluğunun ana binası yüksek duvarlar ve batı cephe önünde bir yapıyla korunmuştur (Resim-6). Çevredeki kalıntılar manastırın geniş bir alana yayıldığını kanıtlamaktadır (Hollerweger, 1999: s.289) (Resim-7/8).

İşte burası, aynı zamanda Süryani Hristiyanlığı açısından manastır hayatının başladığı yerdir. Daha önce de belirtildiği gibi, geleneksel kilise rivayetlerine göre bu manastır IV. yüzyılda Mor Evgin isimli Hristiyan bir münzevi tarafından kurulmuştur. Manastır, sonrasında Tur Abdin Bölgesi'nde inşa edilecek diğer manastırlara da önayak olmuştur. Mor Evgin Manastırı, ilk dönemlerde misyonerlik merkezi ya da konaklama yeri gibi işlevler görmüştür. Örneğin, misyonerliğin kırsal alanlardaki öncüleri olan keşişler, söz konusu bu manastır başta olmak üzere Hristiyanlığı özellikle Nusaybin'in ötesindeki yerleşim birimlerinde yaymaya çalışmışlardır. Ayrıca, Mor Evgin manastırının altından geçen eski ticaret yolunu (tarihî İpek Yolu) kullanan seyyahları büyük bir misafirperverlikle ağırlamışlardır.

V. yüzyılın kilise tarihçisi Sozomenus'un “Aones” diye zikrettiği Mor Evgin (Sozomen, 1980: C.II, Chap.33), Tur Abdin'e monastisizmi getiren ruhanidir (Delehaye, 1948: 139; Wigram, 1910: 232 vd.). Aslen Mısırlı olan Evgin, Kızıldeniz

24 Başkent kilisesi için bkz. Çelik, Bizans, 1999, s.43 vd.; Süryani manastırları için bkz. Çelik, Süryani Kilisesi, s.247 vd.

* Süryanca metinlerin tercümesinde yardımlarını esirgemeyen değerli Hocam Prof. Dr. Mehmet Çelik’e teşekkür ederim. 
kıyısındaki Süveyş (eski Klizma) kentinde ikamet eden bir denizciydi; mesleği inci avcılığı idi. Hayat hikâyesinden öğrendiğimize göre, Mor Evgin, yirmi beş yıl inci ticareti yaptıktan sonra bu fani dünyanın uğraşlarından bıkmış ve Pachomius Manastırı'na giderek burada ruhani hayata intisap etmiştir. Rivayete göre o, bir müddet kaldığı Pachomius Manastırı'ndan da sıkılmış, burayı terk ederek 70 şakirdiyle birlikte Tur Abdin Bölgesi'ne gelmiş ve Nusaybin'deki İzlo Dağı'nda inzivaya çekilmiştir. Evgin, kısa müddet sonra burada bir manastır inşa etmiştir. Kendisi henüz hayattayken bu manastırdaki ruhban sayısının 350'ye ulaştığı rivayet edilmektedir.

Süryani Kadim Kilisesi'nin Mor Evginle ilgili bir baladında, azizin eski gelenek doğrultusunda Mısır'dan kalkıp yetmiş şakirdiyle birlikte Tur Abdin'e gelişini anlatan mısraları bu geleneksel menkıbeyi ölümsüzleştirmiştir (Hollerweger, 1999: 289).

\section{Hor}
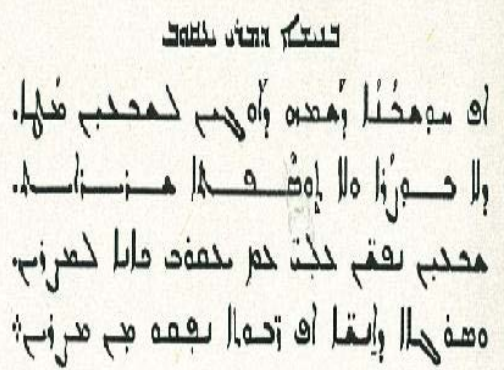

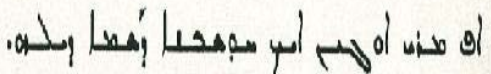

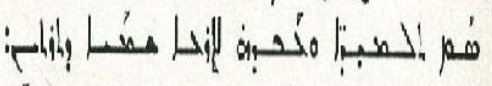

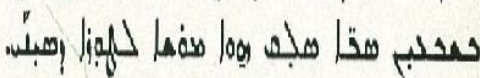

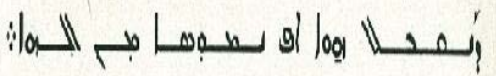

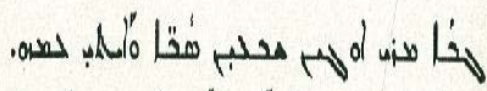

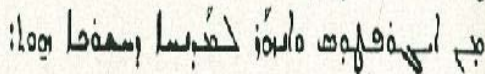

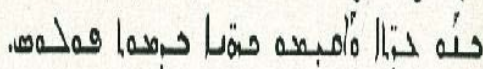

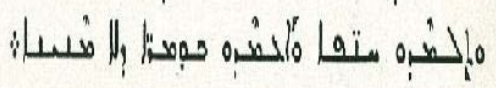

\section{MOR EVGIN}

Evgin isminin sayı toplamı yetmiş eder,

Ne fazlast, ne eksiği var.

Yakub eşliğinde Misır'a yetmiş kişi girdi.

Ancak on binlerden oluşan bir insan

kitlesi çıktı Mısır'dan.

Mor Evgin de isminin sayı toplamı kadar,

Öğrenciler seçerek yeryüzünü ikinci göğe

dönüştürdü.

Şeriat'l Allah'tan kabul etmek üzere,

Yetmiş ihtiyarla çıkmıştı Sina Dağı'na Musa.

Seçtiği yetmiş ihtiyart Mısır'dan

beraberinde getirerek,

Karanliktaki Doğuyu aydınlattı Mor

Evgin.

Kiliseler inşa ederek, kâhinler atadilar Pavlus gibi.

Paganlart hidayete getirerek, liderlerini vaftiz ettiler. 
Mor Evgin'in efsanevi menkıbelerle süslü hayat hikâyesinde, onun bölgede Hristiyanlığı yaydığı ve Nusaybin'in meşhur piskoposu Mor Yakup ile dost olduğu anlatılmakta, ayrıca Yakup'un ileride takdis edileceğine veya Mor Yakup Kilisesi'nin inşasına dair kehanetlerde bulunduğuna dair iddialara da yer verilmektedir. (Akyüz, 1998: 11-14; krş. Keser, 2009: 277-78). Ne var ki, bu gibi bilgilere bilimsel açıdan ihtiyatla yaklaşılması gerektiği de açıktır. ${ }^{25}$

Manastırın çevresindeki kalıntılara bakıldığında, manastır müştemilatının çok geniş bir alana yayıldığı görülmektedir. Muhkem bir kale görünümünde olan manastırın bazı bölümleri kayalara oyularak elde edilmiş olup (Resim - 9) çevre ile oldukça uyumlu bir görüntü çizmektedir.

Manastır, kuruluşundan kısa bir süre sonra el değiştirmiştir. 363 yılında Nusaybin Perslilerin eline geçince Roma'yla yapılan anlaşma gereği şehrin Hristiyan halkından bir kısmı Urfa'ya, bir kısmı ise Diyarbakır'a zorunlu olarak göç etmiştir. ${ }^{26}$ Bunun üzerine Manastır'daki ruhbanlar da Tur Abdin Bölgesi'ndeki diğer manastırlara gitmişlerdir. Bu zoraki göçün sebep olduğu maddi manevi yıkıntıyı, bizzat o göçmenlerden biri olan Mor Efrem şöyle terennüm etmiştir: ${ }^{27}$

25 Mor Evgin hakkında çok çelişkili bilgiler olduğu gibi, birçok araştırmacı bunun bir efsane olduğunu söyler. Bkz. E.C. Butler, 1911, “Monasticism”, The Cambridge Medieval History, (Ed. H.M. Gwatkin-J.P.Whitney), Cilt. I, The MacMillan Company: s. 526.

26 Bu konuda geniş bilgi için bkz. Gregory Abû'l-Farac, Abû'l-Farac Tarihi, (çev. Ö. R. Doğrul), Ankara - 1987, I, s.138; G. Ostrogorsky, Bizans Devleti Tarihi, (çev. F. Işıltan), TTK, Ankara - 1981, s. 47; E. Gibbon Roma Imparatorluğu'nun Gerileyiş ve Çöküş Tarihi, (çev. A. Baltacıgil), İstanbul, 1987-1995, C. II, s. 330 vd.; Percy Sykes, History of Persia, New York - 1958, s. 422; E.R. Hayes, Urfa Akademisi, (çev. Y. Günenç), İstanbul - 2002, s. 130; The Roman Eastern Frontier and the Persian Wars (AD 226-363), (Compiled and Ed. By Michael H. Dodgeon and Samuel N. C. Lieu), Londra ve New York, (Routledge) 2005 s. 422 vd.

27 Şükran Yaşar, Kuruluşundan İslam Fethine Kadar Edessa'nın Siyasi Tarihi, Edessa'dan Urfa'ya I, 2007, I, s.192 


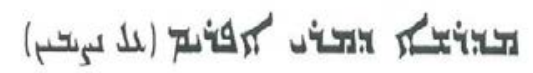

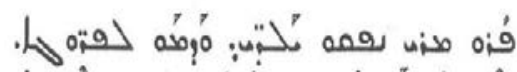

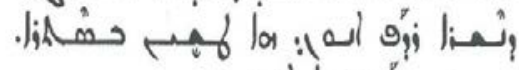
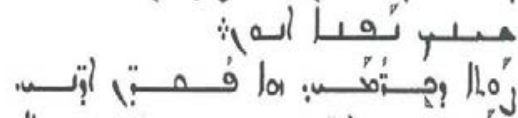

? ثـ

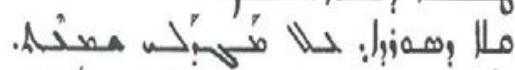

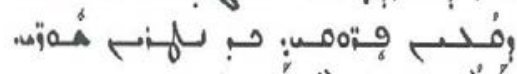

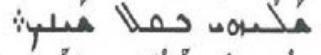

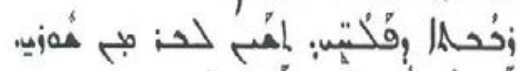

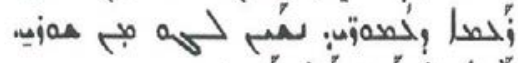
ن

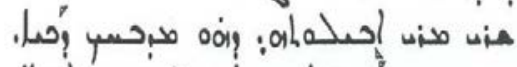

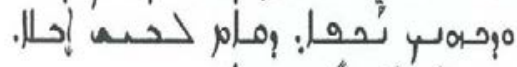

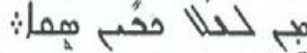

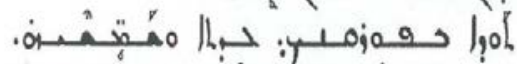

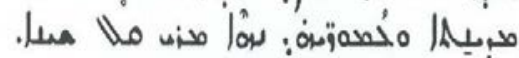
"
Uçup çıktılar yavrularım, civcivler gibi yâ Râb!

Kartal kovaladı̆̆ için, sığınakta gizleniyorlar

Barışın onları geri getirsin

Bağcılarımı dinlemeye can atıyor kulaklarım.,

Ezgileri susturulduğundan, senin kurtuluşunun haberi,

Müjdelerle gürlesin.

Burçlarımın üstünde duydum dehşet sesini,

Bağırarak imdadıma koşanlar koruyor surlarımı,

Yatıştır onu barışının müjdesiyle

Çalışanlarımın feryad,, surumun dışıında

Sakinlerimin gümbürtüsü, surumun içinde güvenliği sağlasın,

Öyle ki, içerde ve dişarda -sanaşükredeyim

O temiz mihrabının

Ve giydiği yasın üstüne çul kuşanmış olarak duran,

Senin iffetli kâhinin mâtemini gider yâ Râb!

Kurtuluşunu itiraf etsin kilise ve şemmaslarl,

Şehir ve sakinleri, Ezgilerinin mükâfatı ise,

Barlşın müjdesi olsun yâ Râb! 
Yukarıda da belirttiğimiz gibi, manastırın kalıntılarına bakılırsa çok geniş bir alana yayıldığı görülmektedir. Avlu çevresinde toplanmış mekân sistemine bakıldığında, genellikle bünyelerinde üç kilise barındıran Tur Abdin bölgesindeki manastırların aksine, Mor Evgin'de bir ana kilise ile bir şapel yer almaktadır. Kilise ve eklentileri bir dış avlu ve yüksek avlu duvarlarıyla çevrilmiştir. Dış avluya geçiş, güneyinden yuvarlak kemerli bir bölümden sağlanmıştır.

Manastırın avlusu mezarlık olarak kullanılmaktadır. Dış avluda, iç avluya girişin hemen yanında; sağ ve sol tarafta birer mezar kitabesi yer almaktadır. (Resim - 10)

Sağ duvardaki mezar kitabesinin Türkçe çevirisi şöyledir:

"Bu fani dünyadan ebediyete intikal etti. Manastırın Başrahibi Deyroyo Lehdo, 1970".

Soldaki mezar kitabesinde ise şu satırlar yer almaktadır:

“Bu satırları okuyan ey büyükler! Abona Antonis rahip Yusuf'u anın. Yusuf Antonis bu zorluklarla dolu hayattan göç etti. Yıl 1878. Rab onu göklerde rahatlatsın. Duaları bizlere yardımcı olsun."

Kilise ve müștemilatı, Manastırın ekte verilen planında da görüldüğü gibi (Resim - 11), bir iç avlunun etrafında toplanmıştır. Dış avludan iç avluya geçiş fotoğraf (Resim - 12) da görüldüğü gibi, zeminden bir metre kadar alçakta, yüksekliği de bir metre civarında olan bir kapıdan geçilerek sağlanmaktadır. i̇ç avlunun etrafı revaklarla çevrilidir. ${ }^{28}$ Revakların içinde mezarlar bulunmaktadır. Batısında dış avluyla bağlantısını sağlayan eyvanlı bölüm, kuzeyinde ise ana kilise yer alır (Resim-13/14).

Manastırın doğusu, iki katlı olarak tasarlanmıştır. Alt katta Beth Qadişe (Azizlerin Evi) (Resim - 15), üst katta ise divanhane yer almaktadır. Azizler Evi'nde Mor Evgin'in 70 şakirdinin mezarları, bu mezar odasının kuzeyinde ise, içinden ufak bir kapı ile geçilen, ışık almayan, karanlık, içerisinde Mor Evgin'in, kız kardeşinin ve bazı akrabalarının yattığı hücre (oda) yer almaktadır ${ }^{29}$ (Hollerweger, 1999: 293).

Beth Qadişe'nin üstünde Divanhane bulunmaktadır. "divanhaneye” ulaşım iç avlunun güneydoğusundan merdivenle ve dış avludan "divanhanenin"

28 Bell, bu iç avluda bulunan kolon başlıklarının Korint düzende olduğunu tahmin ettiğini söyler; Sinclair ise daha önce ince kolonlar üzerinde yer alan sivri uçlu kemerlerin yuvarlak kesitli kemerlerle değiştirildiğini kaydeder. Bkz. Bell, 1982, s. 4-5; Sinclair, 1989 s.346

29 Mor Benyamin'in hayat hikâyesinin yazarına göre (şifahi bir rivayete dayanarak) Mor Evgin ve 10 öğrencisinin kemikleri Mor Benyamin tarafından Deyrü'z-Zaferan Manastıı'na taşınmış ve buradaki Beth Qadişe'ye defnedilmiştir. Ancak bu rivayet dışında bu konuda somut bir delil yoktur. Geniş bilgi için bkz. J. M. Fiey, Nisibe, metropolé syriaque orientale et ses suffragants des origenes á nos jours, CSCO 388, Subsidia 54, (Louvain 1977), s. 137 vd.; Hanna Dolabani, Tarihte Mardin, (Süryanca'dan çev. P. Cebrail Aydın), İstanbul - 2006, (2. baskı), s. 142; P. Gabriel Aydın, Deyrulzafaran Manastırının Tarihi, İstanbul - 1998; Yakup Bilge (2006). Geçmişten Günümüze Deyrulzafaran Manastırı, İstanbul - 2006, s. 71-74. 
kuzeyindeki yuvarlak kemerli bir girişle sağlanmıştır. Dış avlunun kuzeyden üst kattaki "divanhaneye" açılması, manastırdaki kademelenmeyi açıkça göstermektedir.

Kiliseye ise iç avlunun kuzeyinden bir girişle ulaşılmaktadır. Tek nefli, üzeri beşik tonozla örtülü prokial tipte bir yapıdır. Güney duvarında üç açık, doğu duvarında da kapatılmış prokial tipte üç pencere yer almaktadır. Tavanında bir Süryanca kitabe bulunmaktadır. Mezbah'ı (Ayin bölümü), naos zemininden yarım metre kadar (üç basamak) yüksek tutulmuştur. Üzeri yarım daire şeklinde örtülmüştür. Mezbah'ın iki yanında bulunan sütunlar ${ }^{30}$ üzerinde yükselen üç kemer dikkat çeker.

Mor Evgin ana kilisesi tek mezbahlıdır (Resim-16). Yanlarında mezbahtan ve naostan ikişer girişi olan iki oda bulunmaktadır. Kuzeydeki odadan merdivenle, üst kata çıkılır. Burada içinde mezarlar olan ve üstü kubbe ile örtülü bir oda bulunmaktadır.

\section{Sonuç}

Tur Abdin Bölgesi, Hristiyan münzevi yaşamının Doğu Hristiyanlığı ve özellikle de Süryani Hristiyanlığı özelinde neşvünema bulduğu ilk alanlardandır. IV. yy' da Mor Evgin'le başlayan monastik hayat güçlenerek ve giderek organize bir hâl alarak - lakin zaman içerisinde etkisini kaybederek - günümüze kadar gelebilmiştir.

Doğu Hristiyanlığında manastırlar, dünyadan el etek çekmenin, müntesiplerini dünyadan ve dünyevi kötülüklerden korumanın bir aracı olduğu kadar, Kilise ve dinin kurumsallaştığı merkezlerdir. Batı Hristiyanlığının aksine, Doğu'da manastırlar Kilise'nin arka bahçesi değil, kalbidirler. Doğu Hristiyanlığının itikadî - ameli, ilke ve esasları bu manastırlarda belirlenmiştir. Bu manastırlar gerek kendi kiliseleri içinde ve gerekse kendileri dışındaki kiliselerdeki münasebetlerde, karar mercii olmuşlardır. Ayrıca hepsi, birer eğitim ve öğretim kurumudur. Bu manastırlardaki yaşam, tarihi süreç içerisinde ilmek ilmek örülmüş, son derece kurumsal, disiplinli ve düzenli bir yapıya kavuşmuştur. Dünyadan el etek çekmeyi benimseyen bu anlayış aynı zamanda tuhaf bir şekilde seküler alanda düzenlemeler yapacak iştiyaka sahip ve bu uğurda her türlü bedeli ödemeye ve ödetmeye kararlı olup "Sezar'ın hakkına el uzatacak" kadar da dünya ile bağlantılıdır.

Bu makalede, hem Tur Abdin bölgesinde monastik hayatın başlangıcı sayılan -Doğu Hristiyan mistisizminin şaheserlerinden biri olan ve ülkemizin kültürel zenginliğine zenginlik katan- Mor Evgin manastırı, hem de bu manastır bağlamında ortaya çıkan monastik hayat hakkında genel bilgiler verilmeye 
çalışıldı. Gittikçe kurumsallaşan Manastır müessesenin Roma İmparatorluğu'nda din - devlet ilişkileri bağlamında nasıl bir tesir oluşturduğu noktasında da kısaca bilgiler vermeye çalıştık.

Üzerinde önem ve hassasiyetle durulması gereken diğer mesele ise bu muhteşem ve abidevi yapıların manevi anlamlarının yan ısıra maddi açıdan oluşturduğu değerlerdir. Tarihi eserler medeniyet tarihinin en önemli somut objeleridir. Tarih, onlarla anlam kazanır onlarla güzelleşir. Bu yapıların kimlere ait oldukları da önemli değildir. Çünkü hepsi insanlığın ortak malıdır. Osmanlı İmparatorluğu'nun dağılması ve yeni bir devletin yokluklar içerisinde kurulması maalesef bu coğrafyadaki tarihi eserlerin korunmasını zorlaştırmıştır. Ancak gerek bugün içinde bulunduğumuz dönem ve sahip olduğumuz imkânlar, gerekse tarih bilincimizin gelişmesi, bu tür dünya mirası değerlere sahip çıkılması noktasında bize daha hassas bir anlayış kazandırmıştır. Hakkında bilgi verilen ve 1500 yılı aşan varlığıyla tarihe tanıklık eden Mor Evgin Manastıı'nın, 2010 yılından itibaren ziyaretçilerine açık olması bu duruma örnek gösterilebilir.

\section{Kaynakça}

Abû'l-Farac, G. (1987). Abû'l-Farac Tarihi, (Çev. Ö. R. Doğrul), I., Ankara.

Afrahat, (1890). Demonstrations VI. NPNF, Vol. XIII, (ed. Philip Schaff and Henry Wace) The Christian Literature Company, New York.

Akyüz, P. Gabriel, (1998). Nusaybin'deki Mor Yakub Kilisesi ve Nusaybin Okulu, İstanbul.

Atiya, A. S. (2005). Doğu Hristiyanlığı Tarihi, (Çev. N. Hiçyılmaz) İstanbul.

Aydın, P.G. (1998). Deyrulzafaran Manastırının Tarihi, İstanbul.

Bell, G. (1982). The Churches and Monasteries of Tur'Abdin, London.

Bigg, C. (1898).The Doctrine of the Twelve Apostlest, SPCK, London.

Bihlmeyer, K., Tuchle, H. (1972). I. ve IV. Yüzyıllarda Hristiyanlık, (Çev. A. Güral), İstanbul.

Bilge, Y. (2006). Geçmişten Günümüze Deyrulzafaran Manastırl, İstanbul.

Butler, E. C. (1911). "Monasticism" The Cambridge Medieval History, (Ed. H. M. Gwatkin - J. P. Whitney), Vol. I., The MacMillan Company.

Çelik, M. (1999). Siyasal Sistem Açısından Bizans Imparatorluğunda Din- Devlet ilişkileri I, İzmir.

(1987). Süryani Kilisesi Tarihi, Ankara.

(2000). Fener Patrikhanesinin Ökümeniklik Iddiasının Tarihi Seyri (3251453), İzmir.

Ed- Daskaliyye, ev Te'alimu'r Rusûl, (1940). neşr. Hafız Davud, Mısır.

Delehaye, P.H. (1948). "Byzantine Monasticism”, (ed. Norman H. BaynesL.B.Moss), Byzantium: An Introduction to East Roman Civilization, , At the Clarendon Pres, Oxford.

Dodgeon M. H., Lieu S.N.C., (2005). The Roman Eastern Frontier and the Persian Wars $A D$ 226- 363, A. Documantary History, London and New York, Routledge. 
Dolabani, H. (2006). Tarihte Mardin, (Süryanca'dan Çev. P. Cebrail Aydın), (2. Baskı) İstanbul.

Dovernik, F. (1958) The Idea of Apostocility in Byzantium and the Legend of the Apostle Andrew, Harvard Universty Press, Cambridge.

Downey, G. (1961). A History of Antioch in Syria from Seleucus to the Arab Conquest, New Jersey: Princeton Üniversty Press.

Durak, N. (2011). Süryani Ortodoks Kilisesi'nde ibadet, İstanbul.

Ehrman, B.D., JACOBS, A. S., (2004) Christianity in Late Antiquity (300-450), Oxford University Press.

Fiey, J.M. (1977). Nisibe, metropolé syriaque orientale et ses suffragants des origenes á nos jours, $\mathrm{CSCO} 388$, Subsidia 54.

(1977). Nisibe, Métropole syriaque orientale et ses suffragants des origenes a nos jours, Secrétariat du CSCO, Virginia Universty.

Frend, W. H. C. (1979). The Rise of the Monophysite Movement: Chapters in the History of the Church in the Fifth and Sixth Centuries, Cambridge University Press.

George, A. (2006), "Theosis the True Purpose of human Life", Abbot of the Monastery St. Gregorios- Mount Athos

Gibbon, E. (1987-1995) Roma imparatorluğu'nun Gerileyiş ve Çöküş Tarihi, C.II. (çev. A. Baltacıgil), İstanbul.

Hannah, I. C. (1925). Christian Monastisizm, The Macmillian Company, New York. Hayes, E. R. (2002). Urfa Akademisi, (Çev. Y. Günenç), Yaba Yayınları, İstanbul. Hefele, J. (1896). A History of Consils of the Church Vol.Il, T\&TClarke, Edinburg Hollerweger, H. (1999). Canlı Kültür Mirası Turabdin (Çev. Sevil Gülçur) Linz, Değiștirilmemiş üçüncü baskı.

Keser, E. (2009). "Mor Evgin Manastırı", Geçmişten Günümüze Nusaybin Sempozyumu Bildirileri (27- 28 Mayıs 2004), Ankara.

Kirg, G. Middle East From Rise of Islam, New York [t. y.].

Kitabı Mukaddes, (1974). Eski ve Yeni Ahit (Tevrat ve Incil), İbrani, Kildani ve Yunani Dillerinden Son Tashih Edilmiş Tercüme, Kitabı Mukaddes Şirketi, İstanbul.

Lorey, J. (1963). Monks and Monasteries of the Near East (trans. Peter Collin), London.

Ostrogorsky, G. (1981). Bizans Devleti Tarihi, (çev. Fikret Işıltan), TTK Yayınları, Ankara.

Sinclair, T. A. (1989). Eastern Turkey: An Architectural And Archaeological Survey, Vol: III, The Pindar Press: London.

Sozomen, (1980). Ecclesiastical History (HE), NPNF, Vol. II. The Chiristian Literature Company, New York.

Sykes, P. (1958). History of Percia, New York.

Talbot, A. M. (1999). "Bizans Manastır Sistemine Giriş”, Cagito, (Çev. Özden Arıkan), S.17, , İstanbul: Yapı Kredi Yayınları. 
Tertullian, (1873). On Exhortation to Chastity, Translated by S. Thelwall, In The Ante-Nicene Fathers, Vol.4, (ed.) Alexander Roberts and James Donaldson, Edinburgh

Thomas, J. HERO, A. (2000). Byzantine Monastic Foundation Documents, A Complete Translations of the Surviving Founder's Typica and Testaments, Dumbarton Oaks

Valisiev, A. A. (1943). Bizans Imparatorluğu, C.I, (çev. A. Müfid Mansel), Ankara.

(1950). Justin the First: An Introduction to the Epoch Justinian the Great, Dumbarton Oaks Studies I, Cambridge Mass.

Vööbus, A. (1958) History of Ascetism in the Syrian Orient.

Wagner, M. (1950). Saint Basil - Ascetical Works, The Catholic Universty, America Press, Washington.

Wigram, W. A. (1910). An Introduction to the History of the Assyrian Church, Society for Promoting Christian Knowledge, London.

Wishart, W. A. (1990). Short History Monks and Monasteries, Trenton.

Yaşar, Ş. (2007). "Şehrin Sosyo-Ekonomik Yapısı", (Ed. Mehmet Çelik), Edessa'dan Urfa'ya C.I. 489-564, Ankara.

(2007). Kuruluşundan İslam Fethine Kadar Edessa'nın Siyasi Tarihi (Ed. Mehmet Çelik), Edessa'dan Urfa'ya C.I. 127-232, Ankara. 


\section{Ekler}

\section{Resim 1: Tur Abdin Bölgesi}

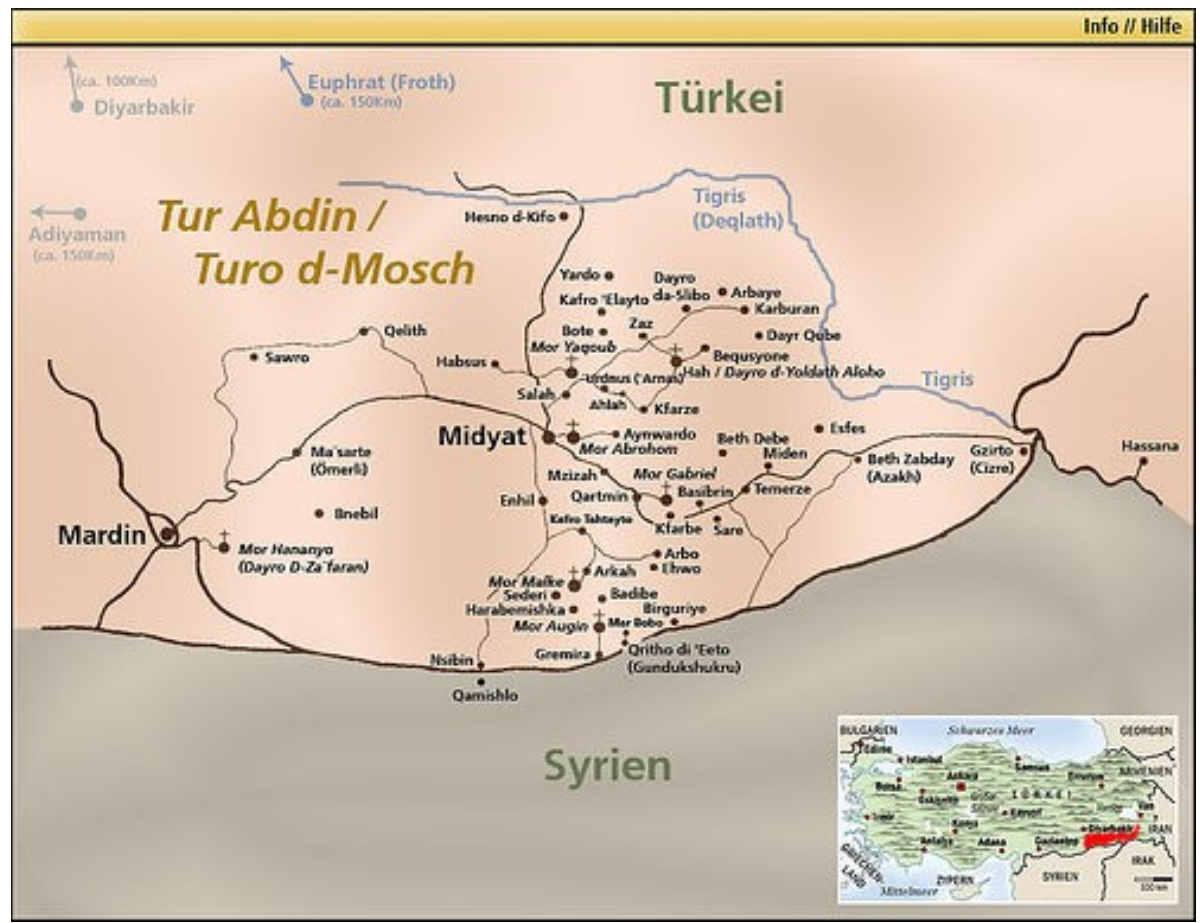

\section{Resim 2: G. Bell'in 1903'teki objektifinden Mor Evgin Manastırı}

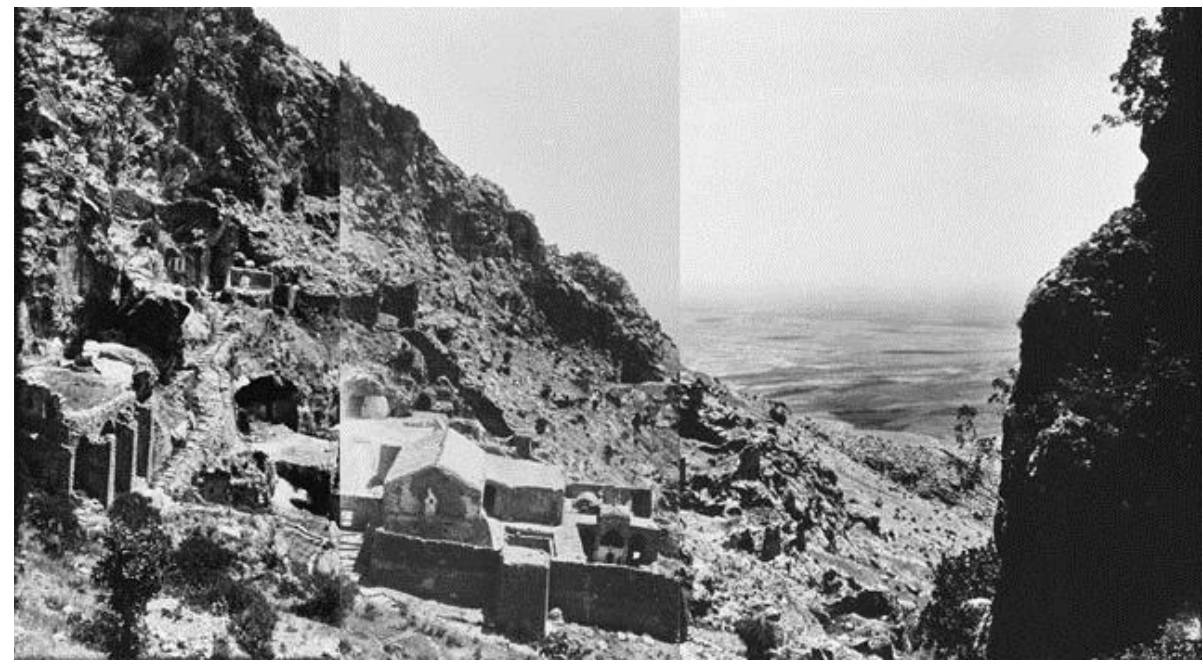




\section{Resim 3:}

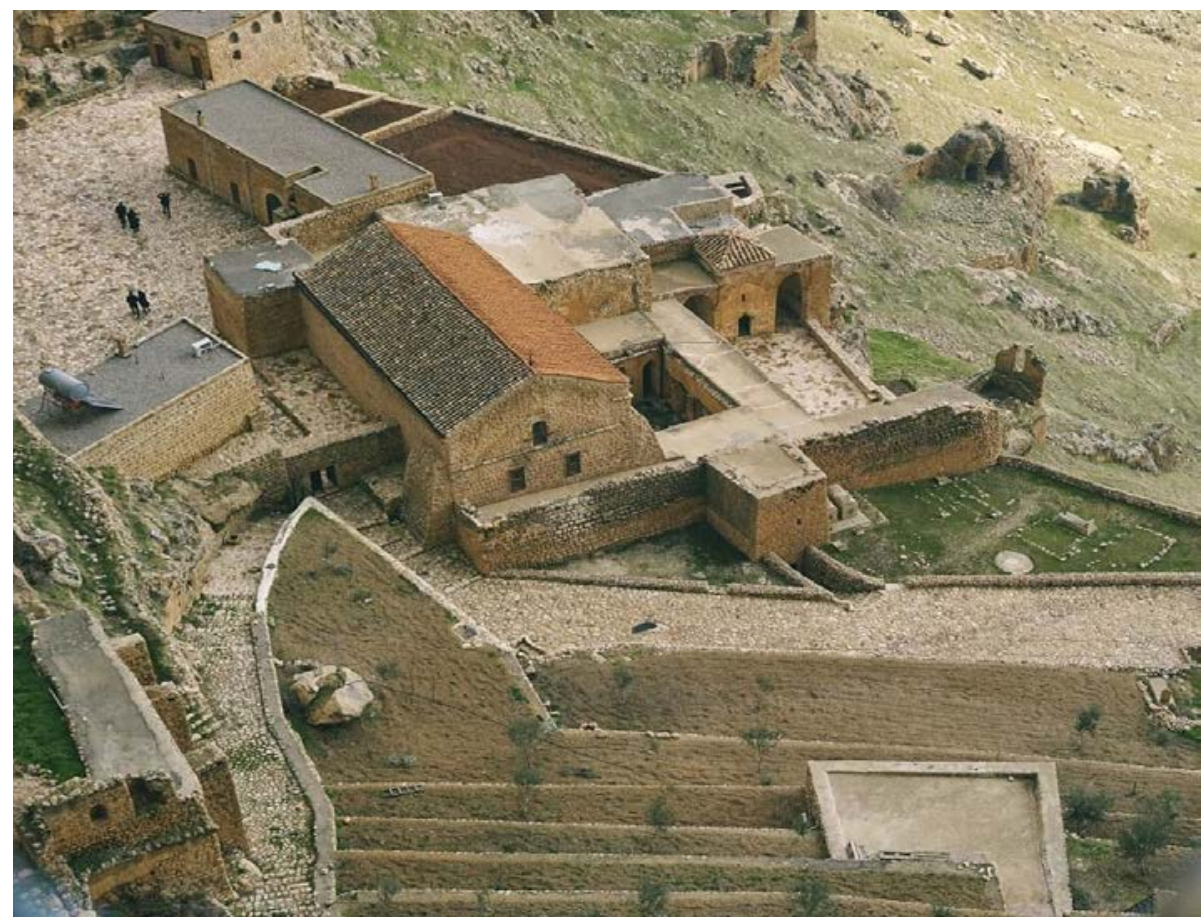

\section{Resim 4:}

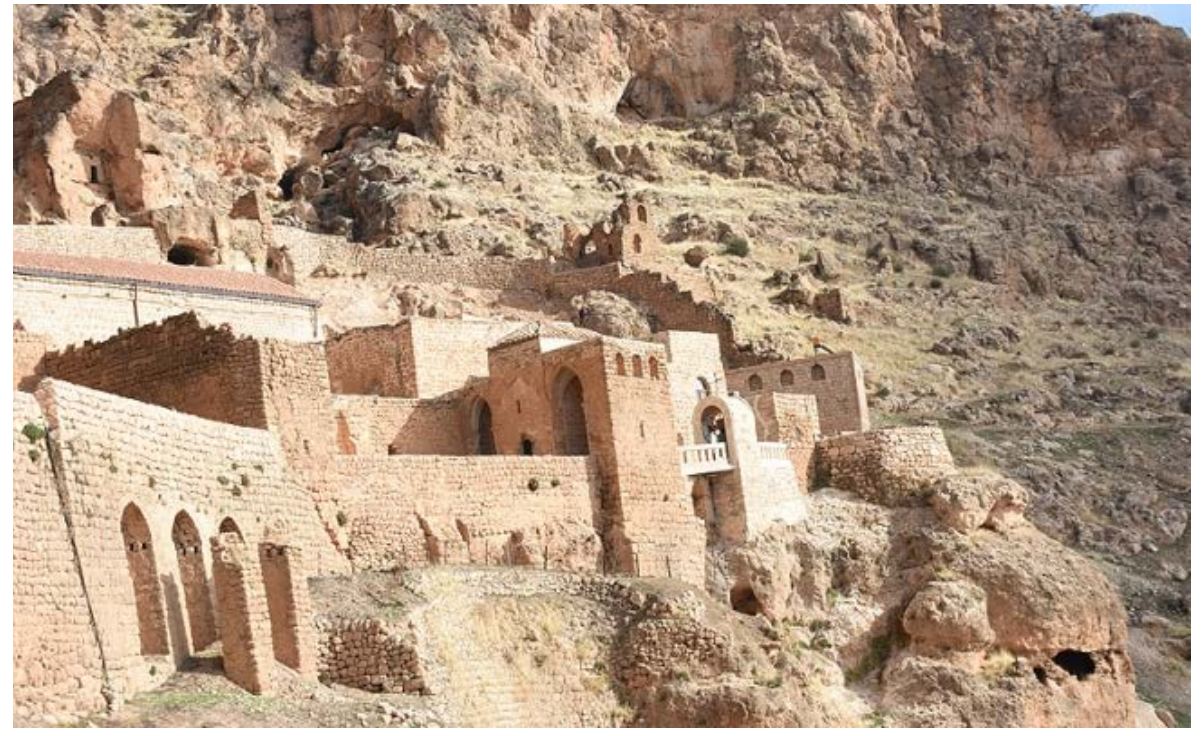


Şükran YAŞAR

\section{Resim 5:}

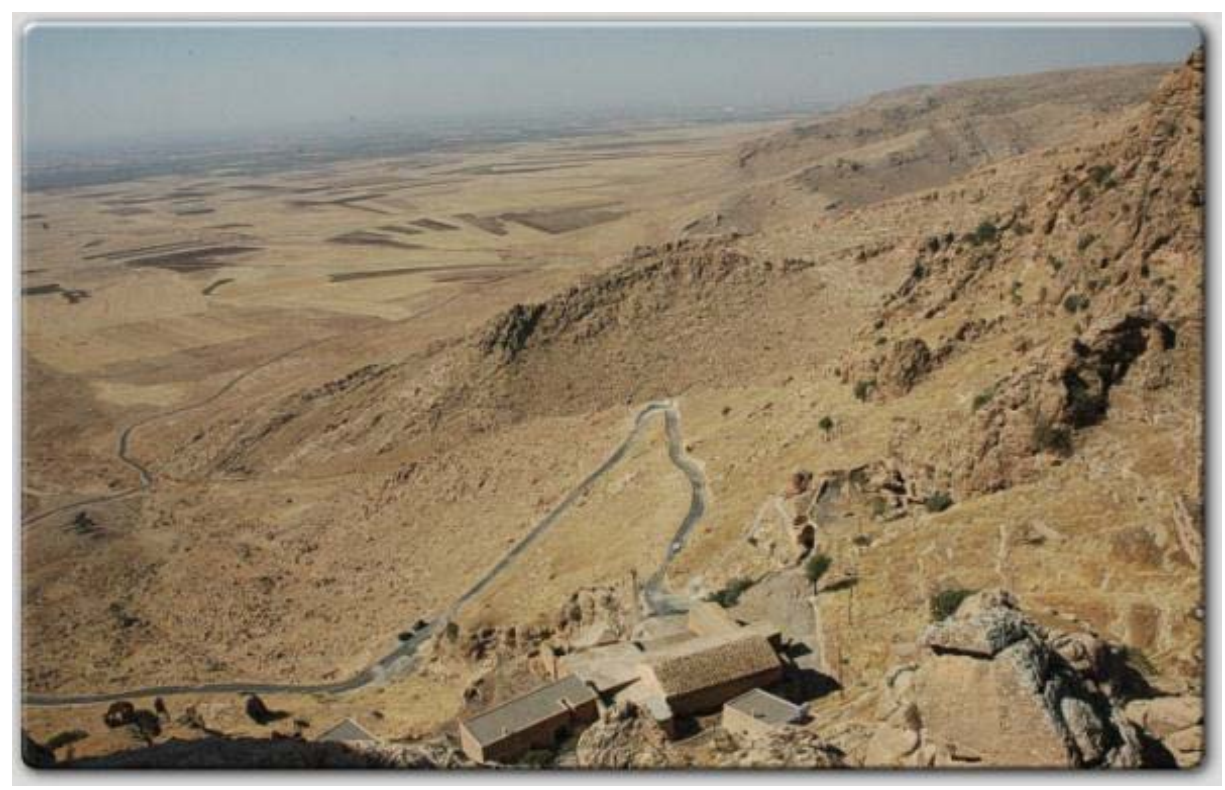

\section{Resim 6:}

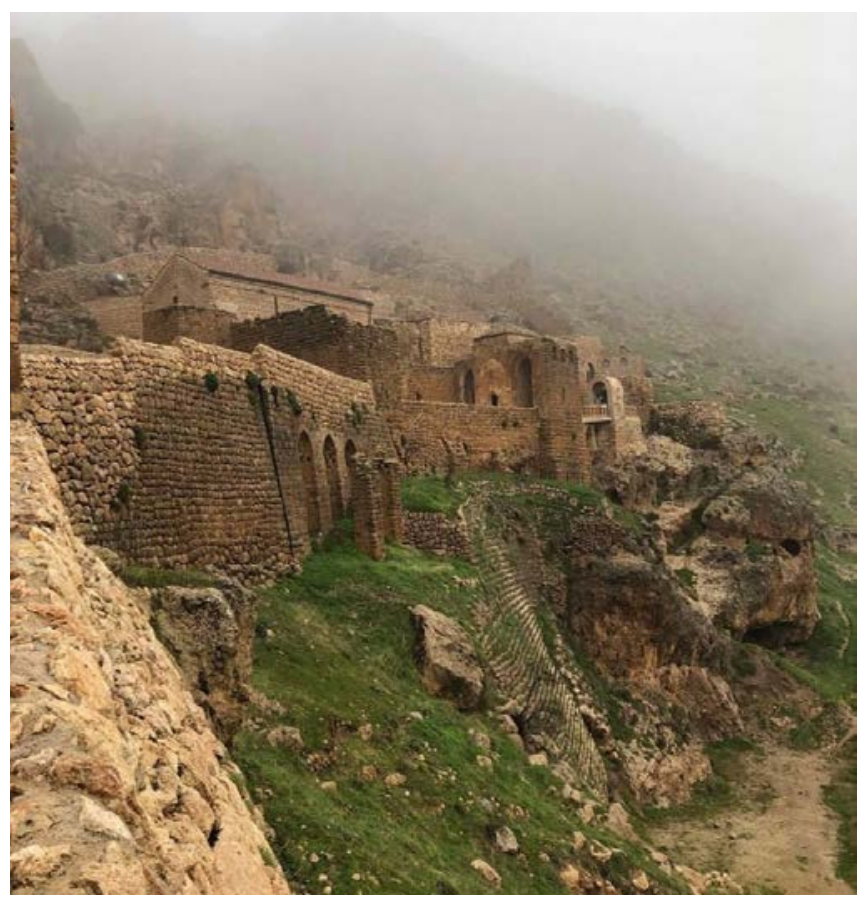


Mor Evgin ve Hristiyan Mistisizminin Tur Abdin Bölgesine Girişi

\section{Resim 7:}

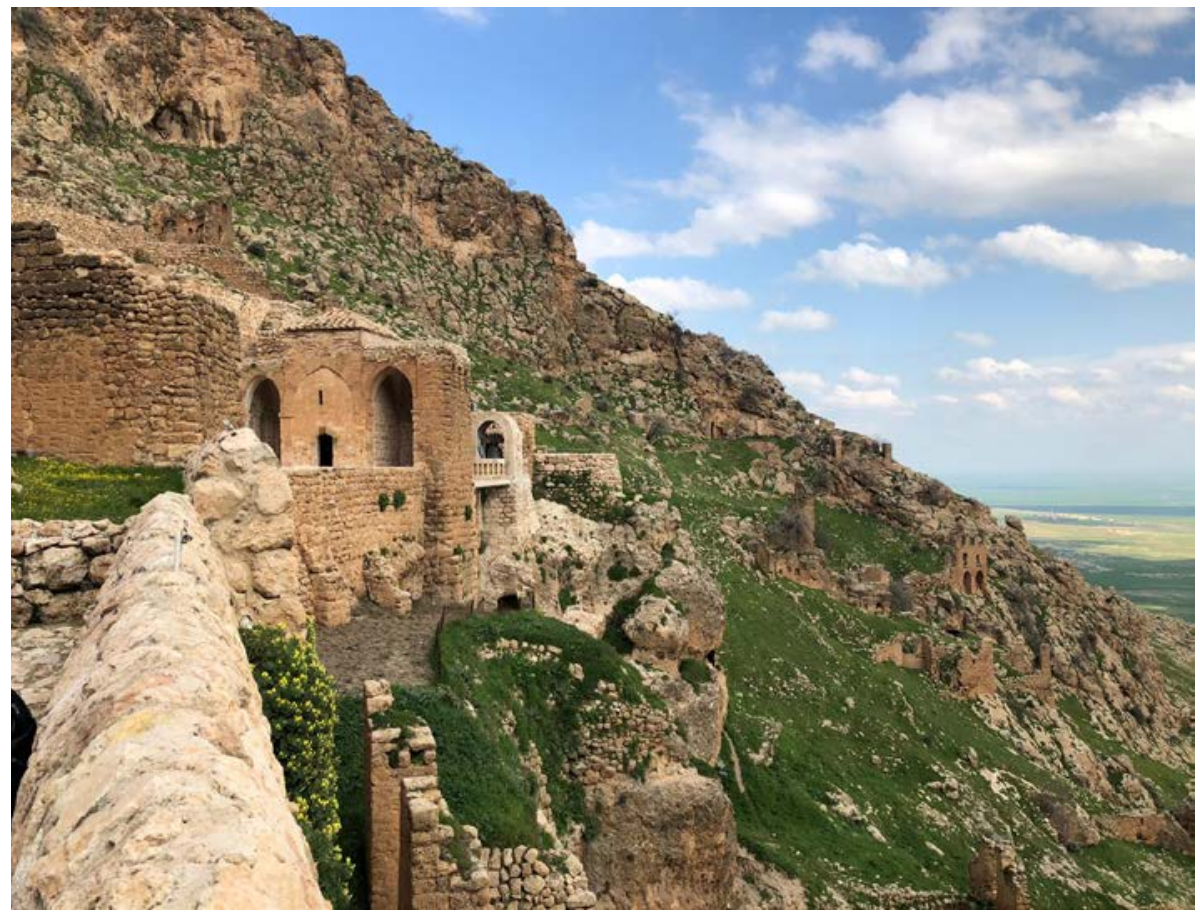

\section{Resim 8:}

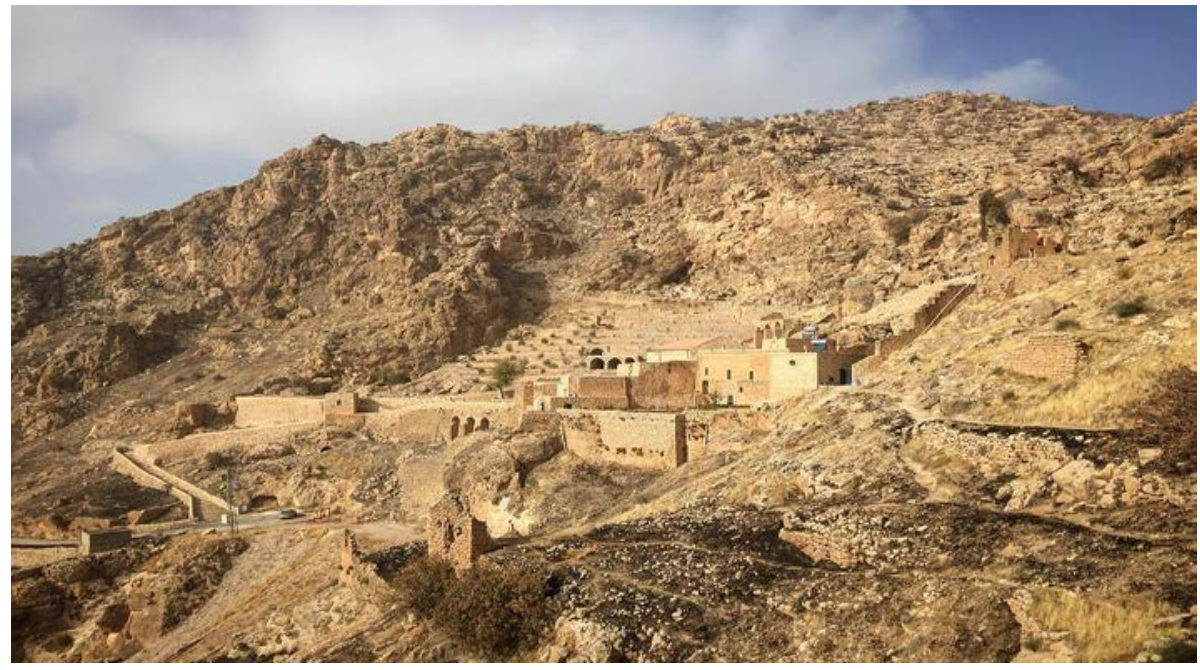




\section{Resim 9:}

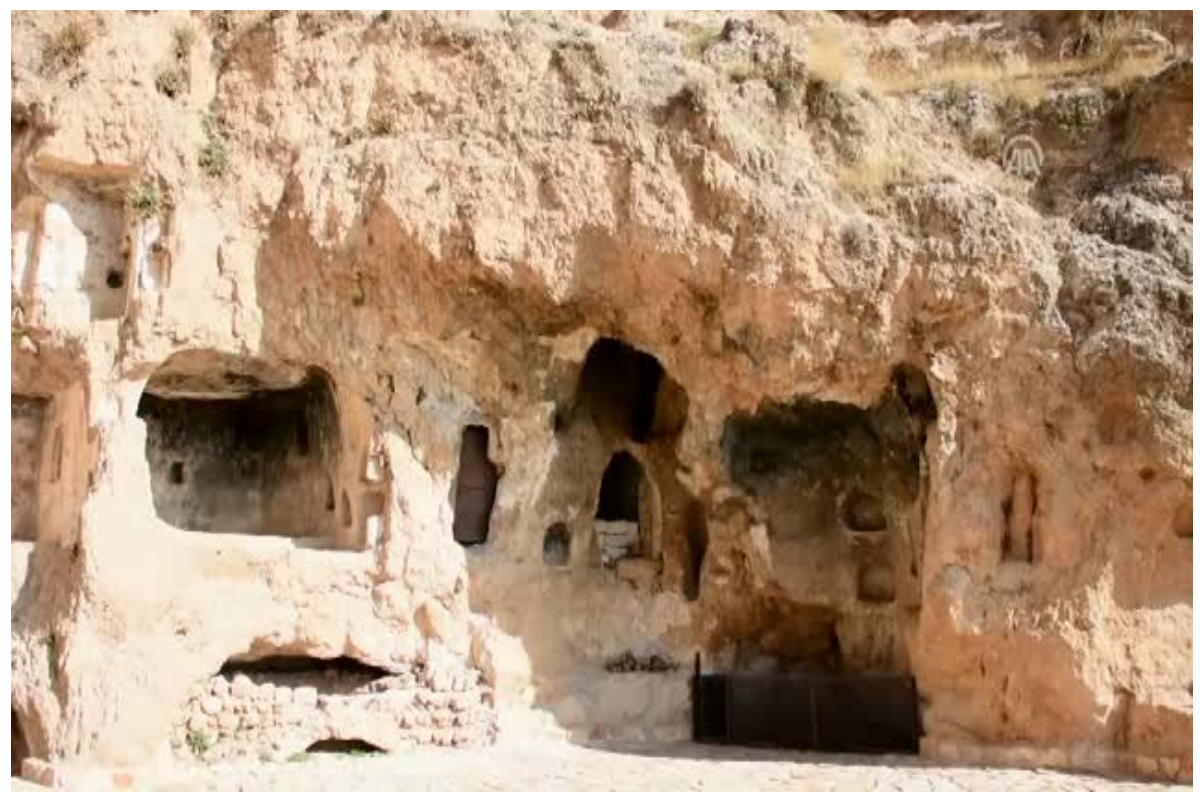

Resim 10: Mezar Kitabesi

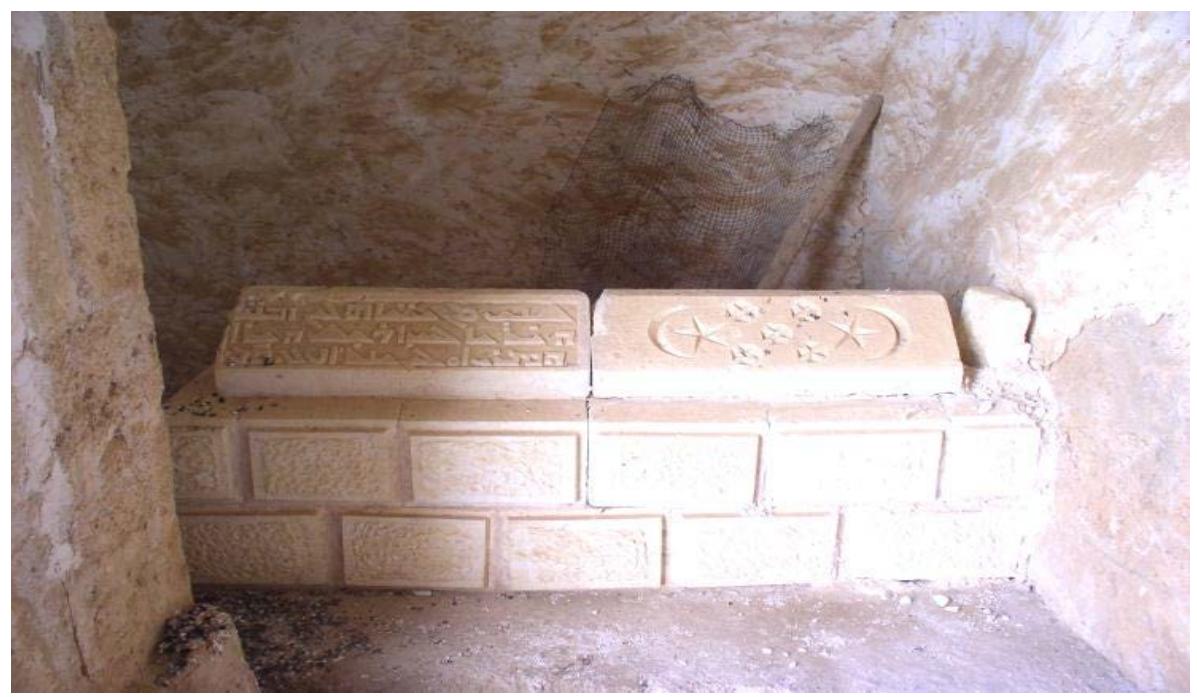




\section{Resim 11: T.A. Sinclair'in Mor Evgin Manastırı Planı}

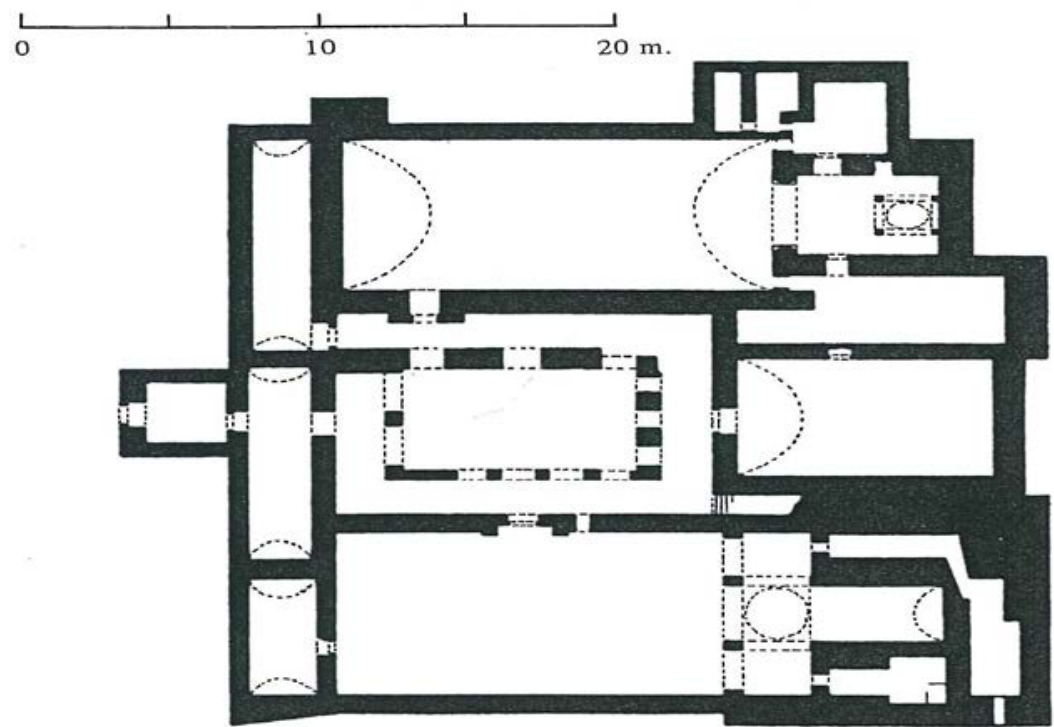

Resim 12: Batıdan İç Avluya Giriş

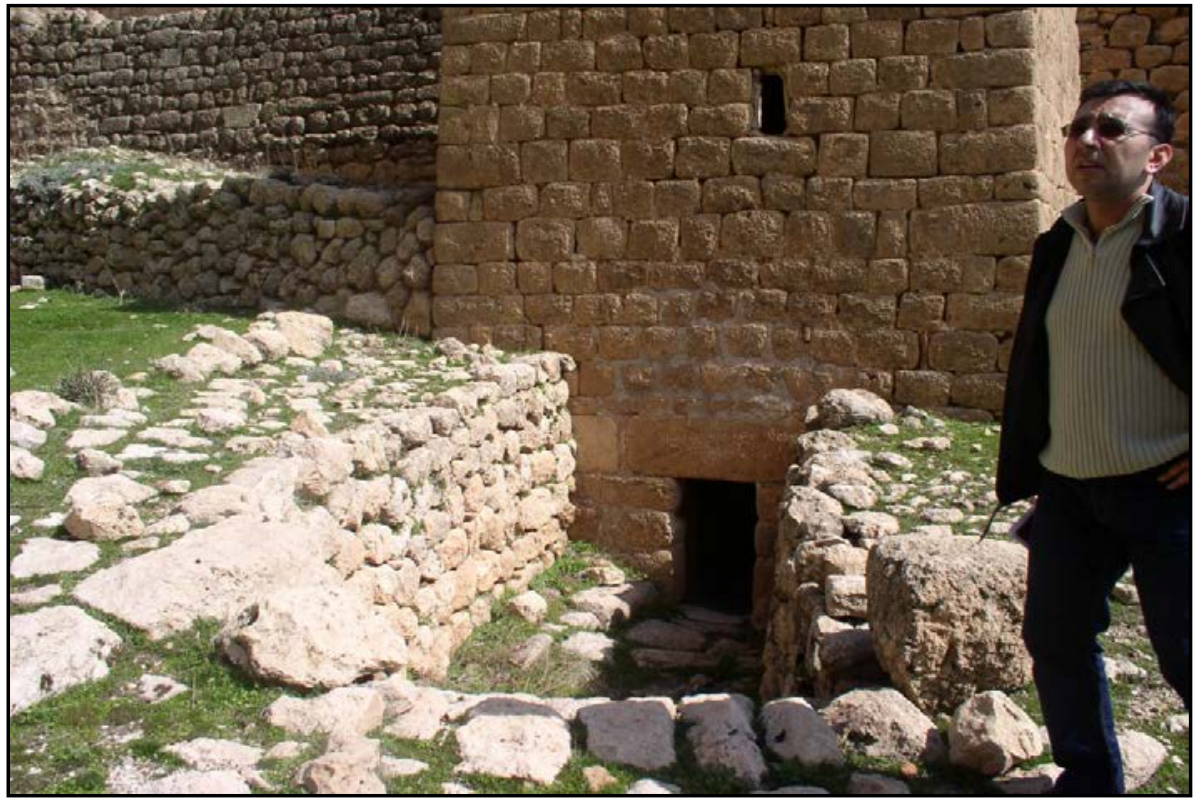




\section{Resim 13: Revaklı iç Avlu}

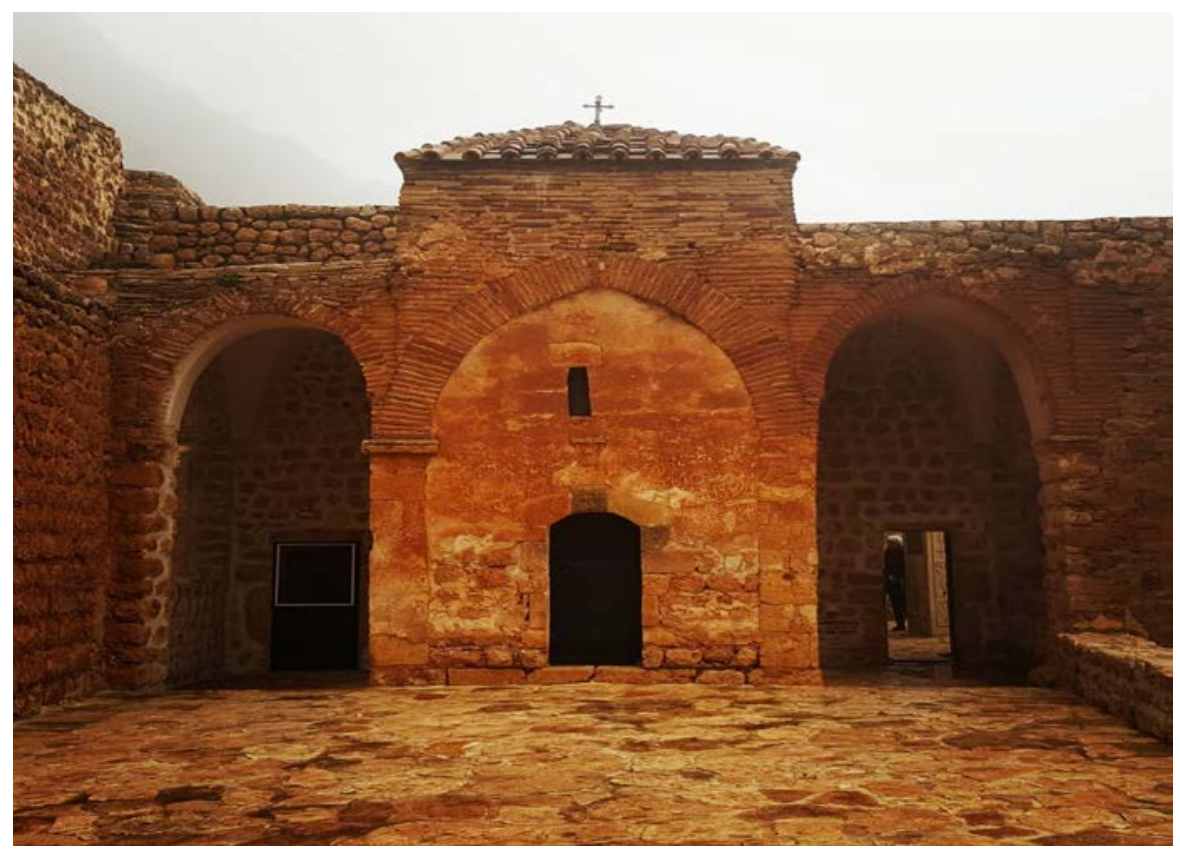

\section{Resim 14:}

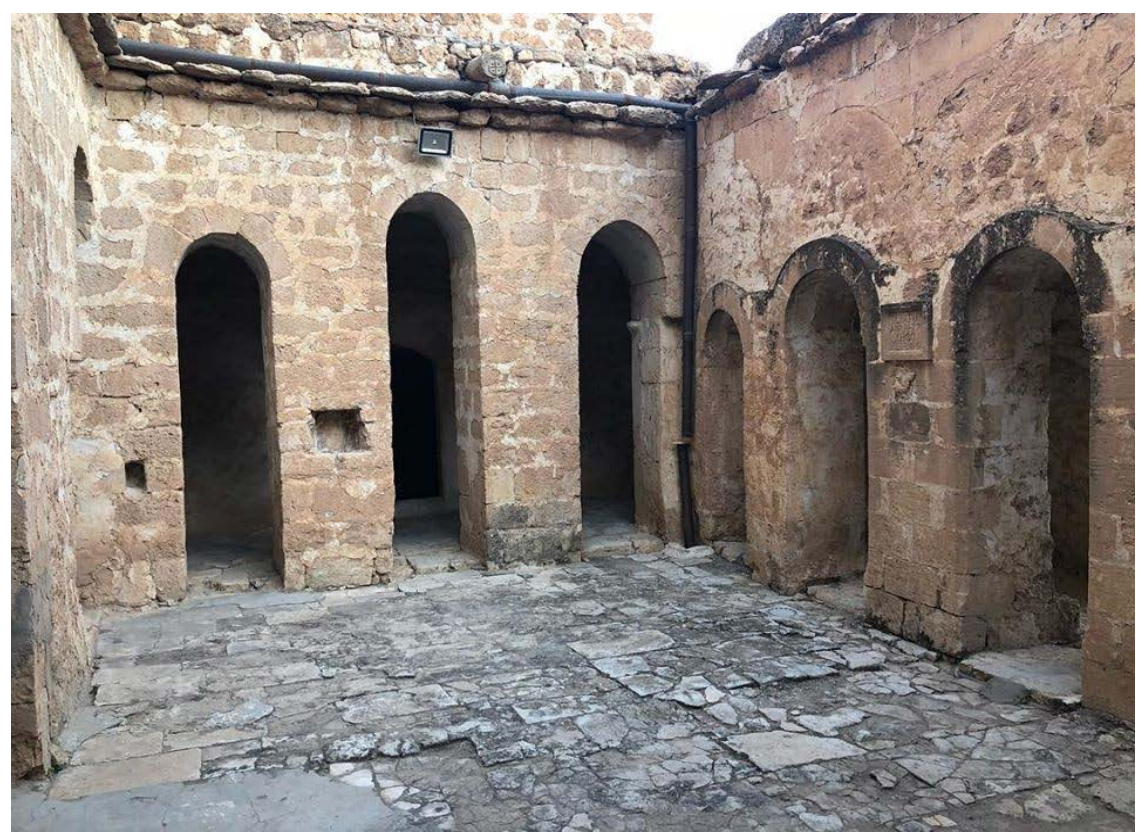




\section{Resim 15: Beth Qadișe (Azizler Evi)}

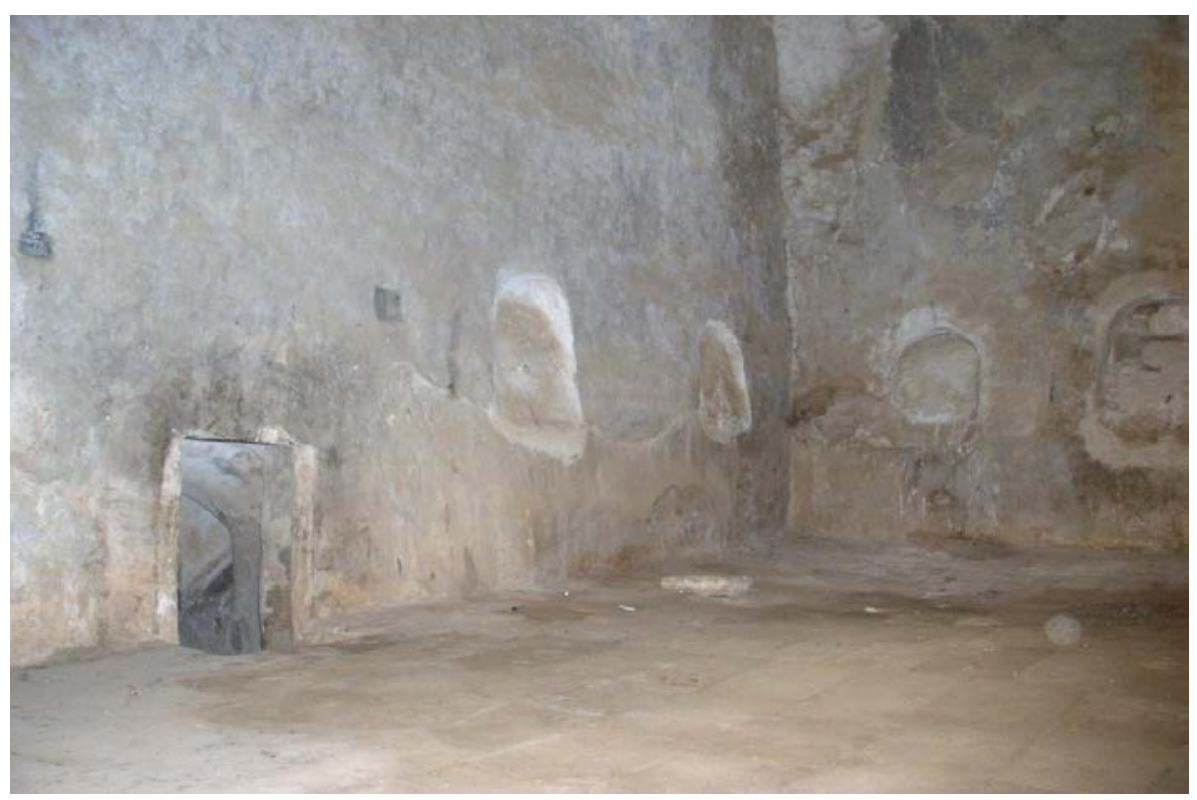

\section{Resim 16: Ana Kilisenin İçten Görünümü}

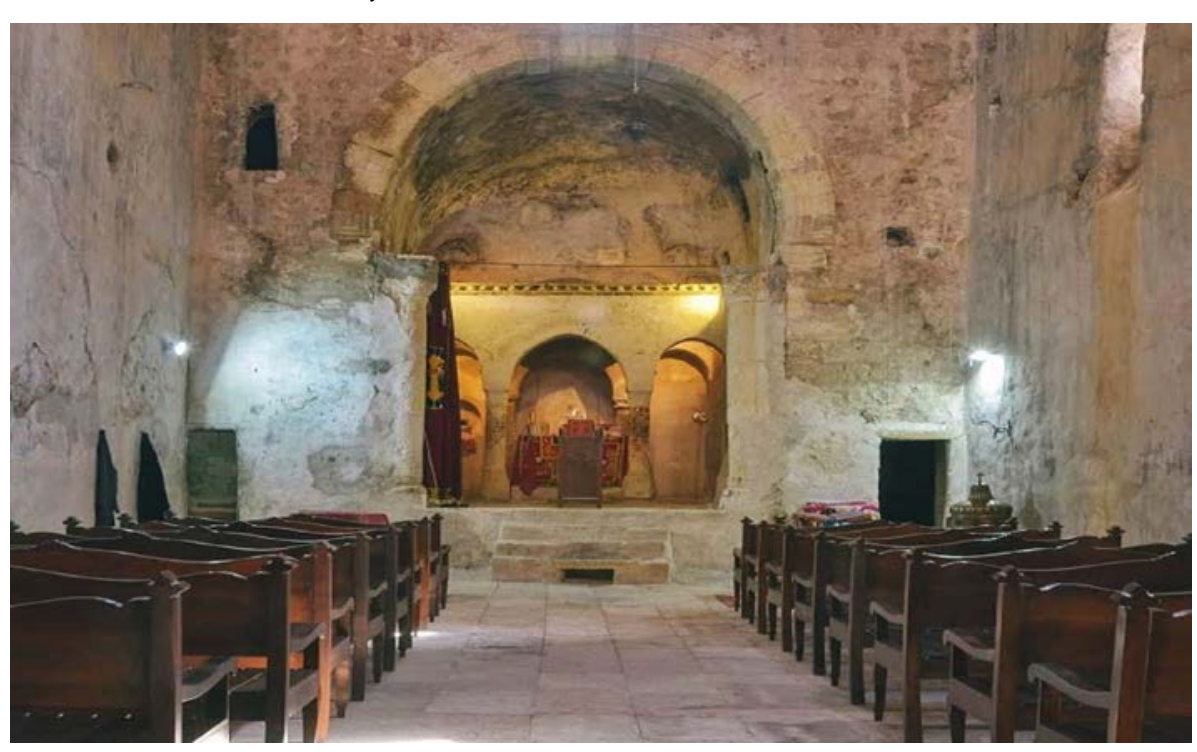

